\title{
The White-headed yellow wagtail Motacilla flava leucocephala (Przewalski, 1887): migration, movements, and breeding and wintering ranges
}

\author{
Flavio Ferlini ${ }^{1 *}$, Elena Alexandrovna Artemyeva ${ }^{2}$, Gombobaatar Sundev $^{3}$
}

\begin{abstract}
The subspecies leucocephala of the western yellow wagtail Motacilla flava is endemic to the Altai-Sayan Ecoregion (Central Asia). The occurrence of leucocephala is associated with saline water bodies and solonchak habitats. Its distribution, especially outside the breeding season, is still uncertain. The aim of this work is to better define the breeding range, migratory movements, and the wintering range of this subspecies and provide guidance to distinguish whiteheaded intraspecific hybrids from the true leucocephala subspecies. The reproductive range of leucocephala is concentrated near lakes and wetlands in the Great Lakes Depression (north-west Mongolia) and in the flat southern part of the Tuva Republic (Russian Federation). The small population uses two separate areas for wintering: the eastern equatorial Africa reached through the Great Rift Valley Flyway and the Indian subcontinent reached along a route that bypasses the great belt of mountains and plateaus of central Asia to the west.
\end{abstract}

Key words: Motacila flava, subspecies, Asia, Africa, Middle East, Indian subcontinent, breeding, wintering, hybrids.

Riassunto - La cutrettola testabianca Motacilla flava leucocephala (Przewalski, 1887): migrazione, movimenti e areali di riproduzione e di svernamento.

La sottospecie leucocephala della cutrettola Motacilla flava è endemica dell'ecoregione Altai-Sayan (Asia centrale). La presenza di leucocephala è associata a corpi idrici salini e a solonchak. La sua distribuzione, soprattutto fuori dal periodo riproduttivo, è ancora incerta. Scopo di questa ricerca è di contribuire a definire meglio l'areale riproduttivo, i movimenti migratori e l'areale di svernamento della sottospecie e fornire indicazioni per distinguere gli ibridi intraspecifici con testa chiara dalla vera sottospecie leucocephala. L'areale riproduttivo della leucocephala è concentrato vicino ai laghi e nelle zone umide nella depressione dei Grandi Laghi (Mongolia nordoccidentale) e nella parte meridionale

\footnotetext{
${ }^{1}$ Società Italiana di Scienze Naturali, Corso Venezia 55, 20121 Milano, Italia.

${ }^{2}$ Ulyanovsk State Pedagogical University of I.N. Ulyanov, sq. of V.I. Lenin 4/5, Ulyanovsk, 432071 Russia.

${ }^{3}$ National University of Mongolia and Mongolian Ornithological Society, P.O. Box 537, Ulaanbaatar 210646A, Ikh surguuli gudamj-1, Mongolia.

* Corresponding author: flavio.ferlini@unipv.it

(C) 2021 Flavio Ferlini, Elena Alexandrovna Artemyeva, Gombobaatar Sundev

Received: 6 May 2020

Accepted for publication: 3 February 2021

Online publication: 16 April 2021
}

pianeggiante della Repubblica di Tuva (Federazione Russa). La piccola popolazione utilizza due aree disgiunte per lo svernamento: 1'Africa equatoriale orientale raggiunta attraverso la Great Rift Valley Flyway e il subcontinente indiano raggiunto lungo un percorso che aggira ad ovest la grande cintura di montagne e altipiani dell'Asia centrale.

Parole chiave: Motacila flava, sottospecie, Asia, Africa, Medio Oriente, subcontinente indiano, nidificazione, svernamento, ibridi.

\section{INTRODUCTION}

The wagtails first appeared in the Eastern Palearctic around 4.5 Ma (megaannum) ago and rapidly dispersed across the Palearctic, reaching Africa, which became a second source of wagtail diversity from around $2.9 \mathrm{Ma}$ ago (Voelker, 2002; Finlayson, 2011). The process that led to the formation of the wagtail species and subspecies has been strongly influenced by climatic changes on the planet. The Croll-Milankovitch theory proposes that climatic oscillations occur through regular eccentricities in the Earth's orbit around the sun every 100, 41, and 21 ka (kiloannum) (Bennett, 1997; Williams et al., 1998). The emergence of modern species of Palaearctic birds (mostly evolving from ancestral species present since the Miocene) happened around 3.5 Ma ago. This data coincides with the main period of Central Asian desert formation and comes after the opening of the Strait of Gibraltar and the flooding of the Mediterranean Sea with the consequent aridification of the climate of the Palearctic (Finlayson, 2011). There was relatively little speciation or extinction among the Palearctic's birds, which instead seem to have responded by adjusting their geographical ranges (Finlayson, 2011). During unfavorable glacial periods, many species experienced range contractions and fragmentations, while expanding again during interglacial periods (Hewitt, 2000; 2004; Holm \& Svenning, 2014). The effects of Ice Ages on species ranges varied with latitude and topography: high latitudes were covered with ice or with permafrost, and temperate and tropical regions compressed towards the equator, increased aridity, reduced tropical forests considerably, while deserts expanded (Hewitt, 2004). Mountain regions between the fortieth parallels were significant because, given available lower land, montane species could descend as the climate cooled and survive oscillations in the same region (Hewitt, 2004). 
Even the appearance and composition of the modern avifauna of Central Asia was shaped during the Ice Ages; the formation processes of subspecies were greatly influenced by the high mosaicity of its landscape elements, which caused biotopic isolation. In addition to glacial fragmentation, a very common category of disjunctions are mountain breaks. For example, in the Altai-Sayan mountain system (nearly 1,065,000 $\mathrm{km}^{2}, 2,000 \mathrm{~km}$ from east to west, and $1,500 \mathrm{~km}$ from north to south, about $62 \%$ located in Russia, $29 \%$ in Mongolia, 5\% in Kazakhstan, and 4\% in China), intermontane basins and their ecological specificity supported the formation of a series of subspecies: Aquila nipalensis nipalensis, Otis tarda dybowskii, Emberiza pallasi lydiae, etc. (Kokorin et al., 2001; Baranov, 2012; 2013).

It is in this context that the "endemic form" leucocephala of the western yellow wagtail Motavilla flava was formed in the Altai-Sayan Ecoregion (Yashina, 2011; Baranov, 2012; 2013) (Fig. 1, 2, 3, and 4).

The occurrence of Motacilla flava leucocephala is associated with saline water bodies and solonchak habitats (Baranov, 2012; 2013). In breeding season, it is distributed only in a limited area, but its distribution, especially outside the breeding season, is still uncertain, as evidenced by the following statements.

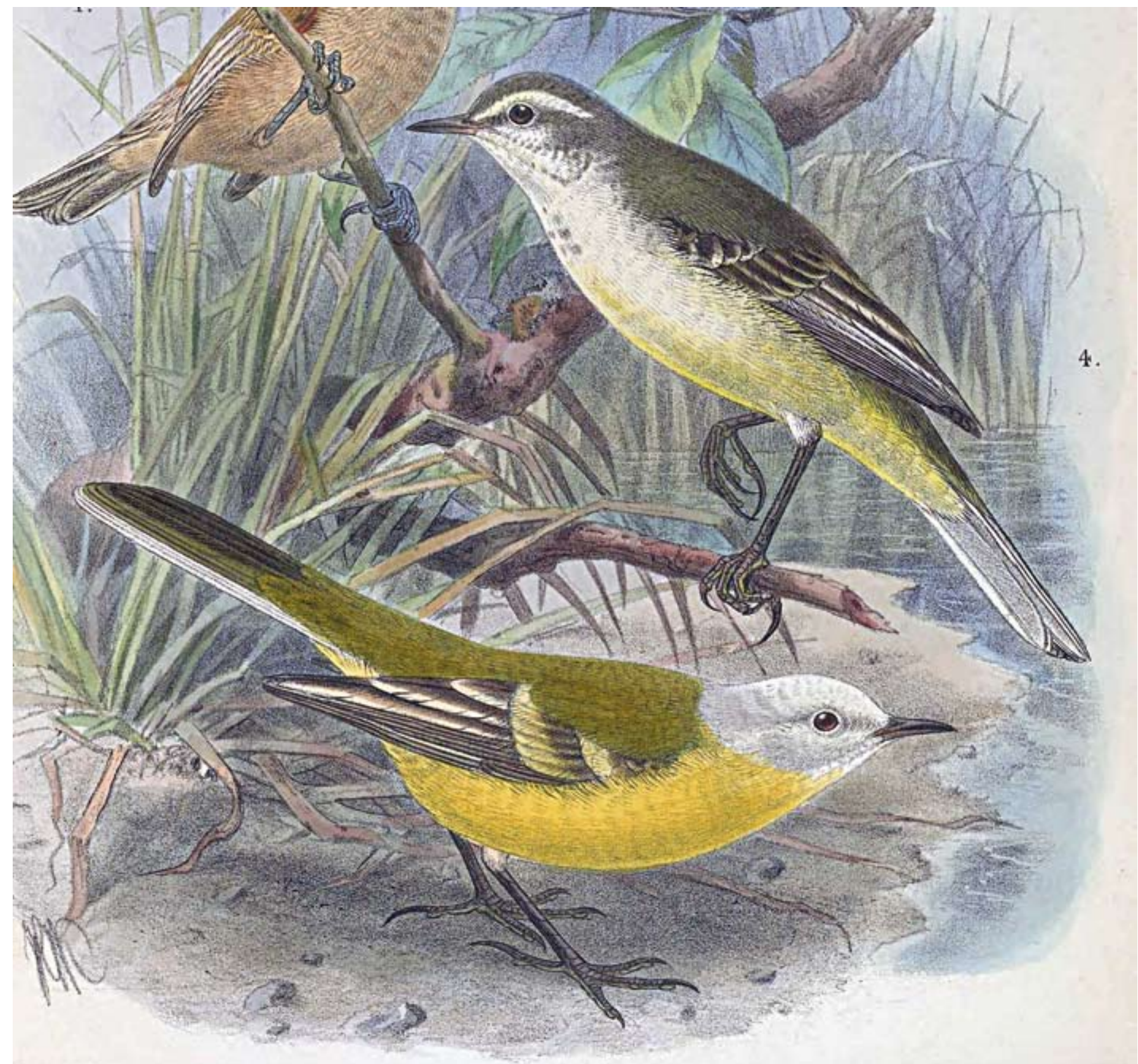

Fig. 1 - Based on specimens collected in 1879 in Central Asia by Russian geographer and explorer Nikolay Mikhaylovich Przewalski, the female and male of Motacilla flava leucocephala were first represented in this color plate (Pleske, 1889). / Sulla base di esemplari raccolti nel 1879 in Asia centrale dal geografo ed esploratore russo Nikolay Mikhaylovich Przewalski, la femmina e il maschio di Motacilla flava leucocephala furono rappresentati per la prima volta in questa tavola a colori (Pleske, 1889). 


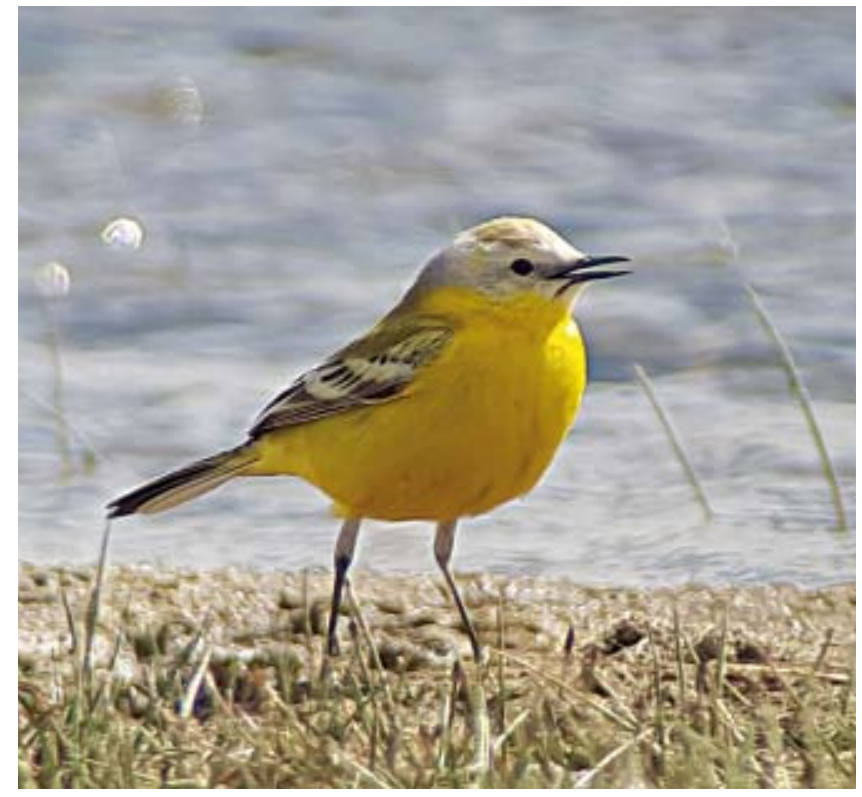

Fig. 2 - Motacilla flava leucocephala. Male, Böön Tsagaan Lake, Bayankhongor Province, Mongolia, 25 $5^{\text {th }}$ May 2019. / Maschio, lago Böön Tsagaan, provincia di Bajankhongor, Mongolia, 25 maggio 2019. (Photo / Foto: Paul French).

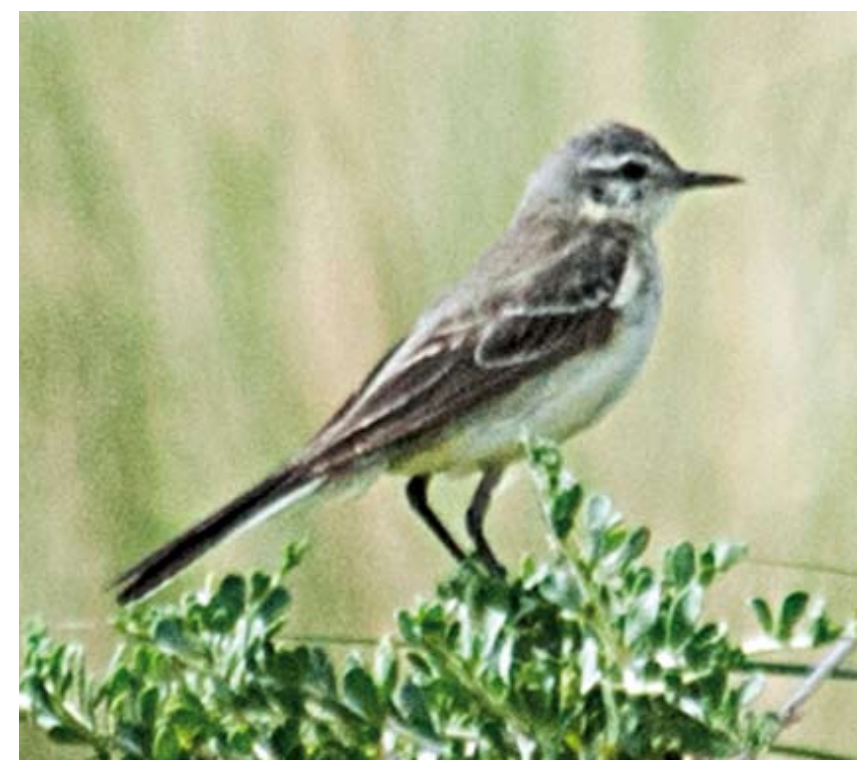

Fig. 3 - Motacilla flava leucocephala. Female, Khar-Us Lake, Khovd Province, Mongolia, 19 ${ }^{\text {th }}$ July 2012. / Femmina, lago Khar-Us, provincia di Hovd, Mongolia, 19 luglio 2012. (Photo / Foto: Gombobaatar Sundev)

«Breeding eastern Russia, Turkestan, and western Mongolia; in non-breeding season to Africa as far south as north-eastern Northern Rhodesia and northern Nyasaland, Arabia and north-western India». (Grant \& MackworthPraed, 1952).

«Outer Mongolia, so far as is known. Winters in India, rarely in Africa». (Williamson, 1955).



Fig. 4 - Motacilla flava leucocephala. Iuvenile, Khar-Us Lake, Khovd Province, Mongolia, 19 ${ }^{\text {th }}$ July 2012. / Giovane, lago Khar-Us, provincia di Hovd, Mongolia, 19 luglio 2012. (Photo / Foto: Gombobaatar Sundev).

«Northwestern Mongolia in the region of the Achitu Nor and perhaps northwestern Dzungaria in the region of the Ulyungur Nor and the basin of the Urungu. Birds indistinguishable from the race breed occasionally on the Kirghiz steppes. Migrates through Mongolia and Russian Turkestan to India in northwestern Punjab». (Mayr \& Greenway, 1960).

«Breeding largely in north-west Mongolia, moves west of south to winter in north-west India». (Cramp, 1988).

«Breeds Central Asia; winter range unknown, possibly Pakistan». (Beaman \& Madge, 1998).

«North-western Mongolia and the Tuva region in adjacent Siberia, and probably also in the neighbouring parts of northernmost Xinjiang, China. It probably winters mainly in India, but the exact wintering grounds are not known. Occurs in Xinjiang, Pakistan and probably Afghanistan, Uzbekistan, and Turkmenistan during migration. Also a vagrant to East Africa south to Zambia and Malawi, with several sightings in e.g. Kenya. During migration it is a vagrant in the Middle East and Iran». (Alström et al., 2003).

«Breeds NW Mongolia, extreme NW China (Xinjiang) and adjacent parts of former URSS; winters probably mostly in India». (Tyler, 2004).

«SE Altai, NW Mongolia, NW China, but details poorly known, and frequently impossible to locate when searching for it within claimed breeding range; winters SE Africa and SW Asia». (Shirihai \& Svensson, 2018). 
The various opinions expressed by authoritative ornithologists regarding the distribution of the leucocephala subspecies of the western yellow wagtail, both during the breeding season and in winter, may seem paradoxical having passed well over a century after the description given by general Przewalski (1887a; 1887b). However, analyzing the data available today, we immediately realize that there are many valid reasons that led to this continuing uncertainty. The main ones can be summarized as follows:

- breeding range located in some geographical areas not easily accessible to researchers

- low density of the subspecies in the breeding range and in winter quarters

- possible confusion with leucistic individuals belonging to other species/subspecies

- possible confusion with pale headed individuals generated from the coupling of different subspecies (e.g. lutea $\mathrm{x}$ beema or flava $\mathrm{x}$ flavissima)

- presence of intermediate subjects deriving from leucocephala and beema mixed pairs.

The aim of this research is to better understand the breeding range, migratory movements, and the wintering range of Motacilla flava leucocephala and provide guidance to distinguish light-headed intraspecific hybrids from the true leucocephala subspecies.

\section{MATERIALS AND METHODS}

The study is based on data and information obtained from 178 bibliographic sources, 29 travel reports, databases (including 5 relating to museum collections), and a few websites. Analyzing the photographic documentation, we have only considered male individuals, as females can easily be confused with that of the beema subspecies.

\section{RESULTS \\ Breeding range of Motacilla flava leucocephala}

Although the subspecies was known as early as 1879 and had been officially described in 1887 (Przewalski, $1887 \mathrm{a} ; 1887 \mathrm{~b}$ ), in 1911 a nesting site was discovered for the first time; a clutch of two eggs was found on $13^{\text {th }}$ July along the northwestern coast of the Achit Lake, north-west Mongolia (Grum-Grzhimaylo, 1914; Sushkin, 1925a; $1925 \mathrm{~b})$. In the same area on $30^{\text {th }}$ June 1914 , another nest was found with three eggs (probably a replacement brood) (Sushkin, 1938; Harvard University M \& Morris, 2019). On $7^{\text {th }}$ June 1926 , a pair was present along the north-eastern shore of the Orok Lake (now Orog Lake), but Kozlova (1933) could not verify its nesting.

In Mongolia, the presence of birds during the reproductive period was recently confirmed, especially near lakes.

At the Achit Lake (Uvs Province) (Fig. 5), one individual was on the south-western shore on $30^{\text {th }}$ May 2007 (Malmae-

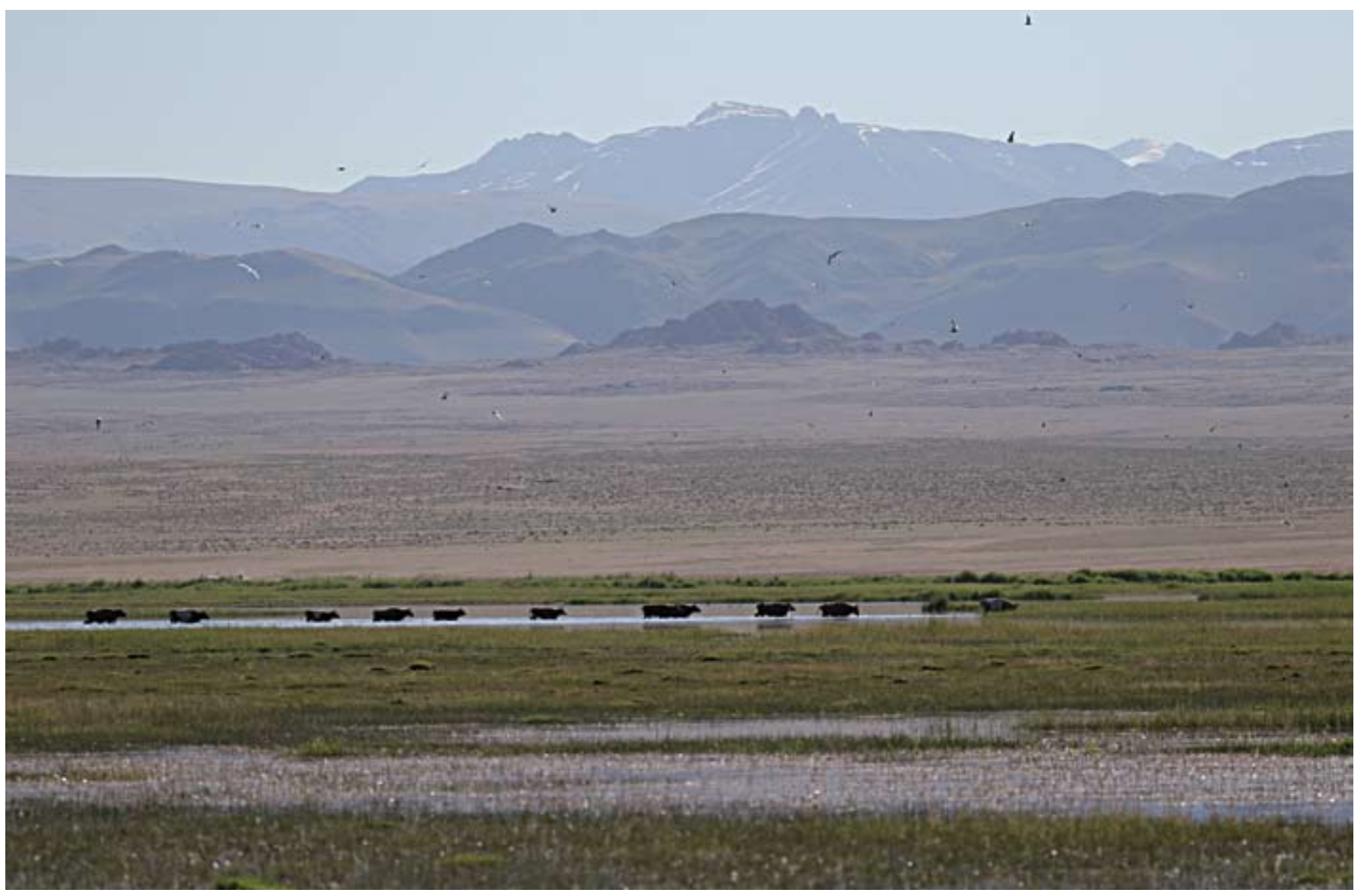

Fig. 5 - Achit Lake, Uvs Province, Mongolia, 14 ${ }^{\text {th }}$ June 2017. / Ačit Nuur, provincia di Uvs, Mongolia, 14 giugno 2017. (Photo / Foto: Magnus Hellström). 
us, 2007), at least three males were on the north-eastern shore on $18^{\text {th }}$ June 2009 (not near the south-eastern edge of the lake) (Faveyts, 2009), and one bird was on the south-western shore on $26^{\text {th }}$ June 2013 (Rubythroat Birding Tours, 2013). Some individuals were recorded also on $22^{\text {nd }}$ June 2016 (Valkenburg, 2016) and on $14^{\text {th }}-15^{\text {th }}$ June 2017 (Hellström, 2017).

At Airag Lake (Uvs Province), dozens were observed on $12^{\text {th }}-13^{\text {th }}$ May 2007 (Bayarhuu \& Bräunlich, 2007; Bräunlich, 2007a).

At Bayan Lake (Uvs Province), one male was photographed and filmed on 18 $8^{\text {th }}$ July 2014 (Ennoil0202, 2014).

At Khar-Us Lake (Khovd Province), one specimen was collected on $8^{\text {th }}$ July 1976 (Redkin, 2001), 20 individuals were present on $9^{\text {th }}$ June 2005, and 75 were present on $10^{\text {th }}$ June 2005 (John Allcock in eBird.org, 2019). Some specimens were recorded in early-May 2007 (Bräunlich, 2007b), in June 2012 (Buchheim, 2013; Buchheim \& van der Heyde in Heiss \& Eidam, 2015), and on $26^{\text {th }}$ June 2013 (Shnayder, 2013). At the same lake, some specimens were observed on $4^{\text {th }}$ June 2015 (Visa Rauste in Tarsiger.com, 2019), 26 $6^{\text {th }}$ June 2016 (east coast) (Valkenburg, 2016; Morten Venas in IBC, 2019), $1^{\text {st }}$ July 2016 (quite numerous) (Dubois, 2016), 10 ${ }^{\text {th }}$ June 2017 (Jargal Lamjav in Flickr.com, 2019), 22 ${ }^{\text {nd }}$ June 2017 (Yann Muzika in orientalbirdimages.org, 2019), and 3 birds were present on $26^{\text {th }}$ May 2018 (Tuvshintugs Sukhbaatar in eBird, 2019). During the breeding season (June) in 2012-2018, we counted 7-11 breeding pairs on western and south-western shores with reedbeds (Gombobaatar, pers. com.).

At the Khar Lake and Dörgön Lake (Khovd Province), 20 individuals were present on $11^{\text {th }}$ June 2005 (John Allcock in eBird.org, 2019).
Further south, in the Gobi-Altai Province, at least two pairs and other individuals were recorded at Bayantooroi, an irrigated cropping settlement in a Gobi Desert oasis, $62 \mathrm{~km}$ south of Tsogt sum center on $27^{\text {th }}$ June 2016, and on the same day, almost 3 birds (one with a grayer head) were seen at Alag Lake (largely dry in the middle of the desert with a very swampy environment with phragmites, $45^{\circ} 08^{\prime} 00^{\prime \prime} \mathrm{N} 94^{\circ} 30^{\prime} 00^{\prime \prime} \mathrm{E}, 1,033 \mathrm{~m}$ a.s.l.) (Dubois, 2016).

Recently, at Böön Tsagaan Lake (a large lake in Bayakhongor Province in the Gobi Desert), Paul French (pers. com.) observed the leucocephala on two occasions: a male and female together on $6^{\text {th }}$ June 2018, and one male on $25^{\text {th }}$ May 2019.

In the northern part of the Great Lakes Depression, the leucocephala was present in the endorheic basin of the Uvs Lake, through which it penetrated into the south of the Tuva Republic (Russian Federation) (Stepanyan, 1990; Tsvetkov et al., 2003; Koblik et al., 2006). Like beema, leucocephala nested only in the flat parts of the Republic, not penetrating the mountainous regions (Tsvetkov et al., 2003). Nesting white-headed yellow wagtails were established along the banks of the lakes Uvs, Shar-Nuur, Tere-Khol (Fig. 6), and Dus-Khol between the Oruku-Shina and Kosh-Terek rivers (Tsvetkov et al., 2003; Baranov, 2007; Redkin, 2011).

At Uvs Lake, one specimen was collected on $27^{\text {th }}$ June 1987 on the northern coast (Redkin, 2001). At Tere-Khol, one specimen was collected on $29^{\text {th }}$ June 1989 (Redkin, 2001 ), and on the southern shore two specimens on $10^{\text {th }}$ June 1999, two specimens on $23^{\text {rd }}$ June 1999 , and two specimens on $18^{\text {th }}$ June 2000 were collected (Faucett, 2016).

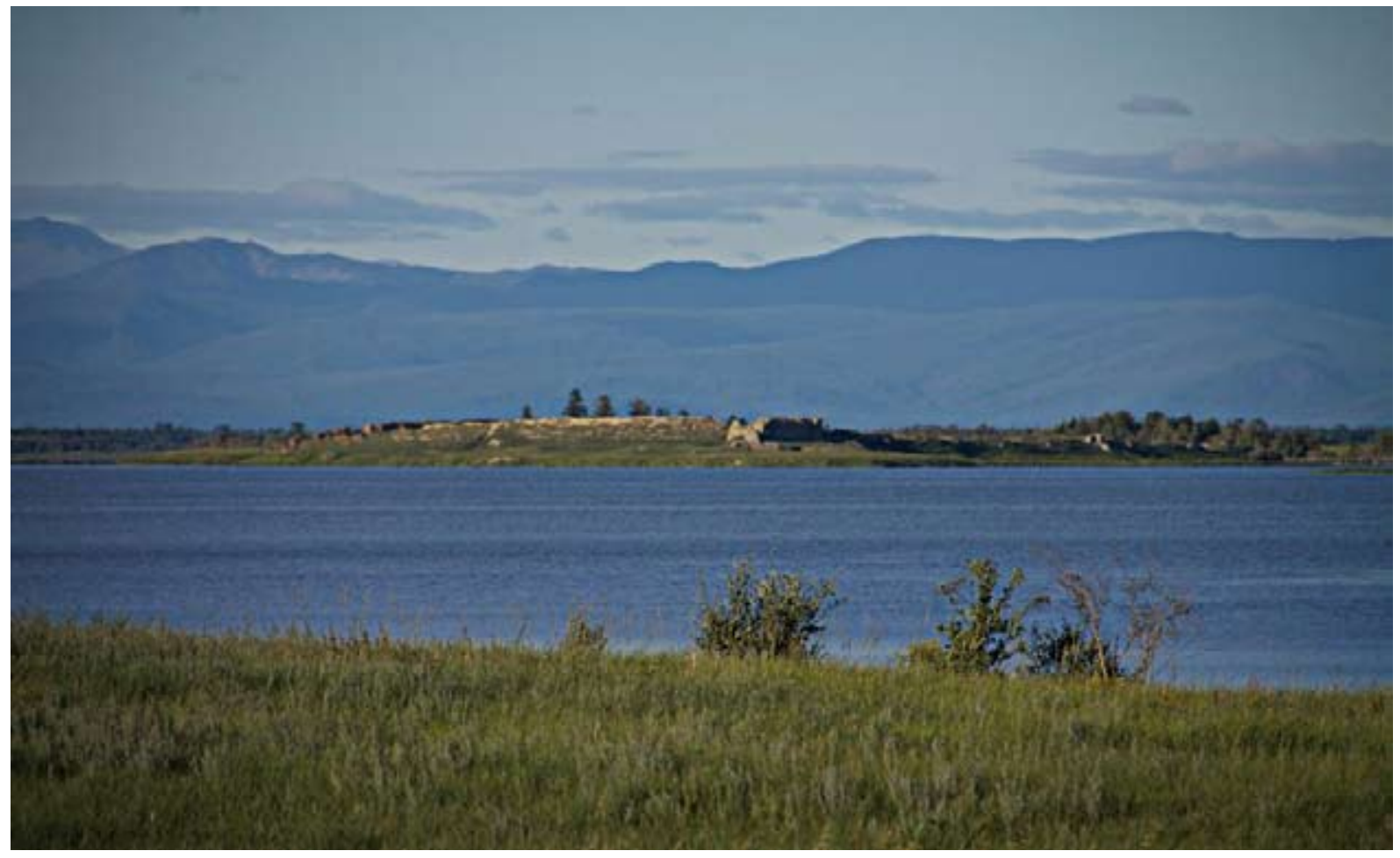

Fig. 6 - Por-Bazhyn, ruins of the ancient Uyghur fortress in Tere-Khol Lake, Tuva, Russia, 27 $7^{\text {th }}$ July 2011. / Por-Bazhyn, rovine dell'antica fortezza uigura nel lago Tere-Khol', Tuva, Russia, 27 luglio 2011. (Photo / Foto: Zachary Collier, from flickr.com, CC BY 2.0). 


\section{Migratory movements and wintering range of Motacilla flava leucocephala}

The white-headed yellow wagtail was first discovered by Przewalski (1887a; 1887b) in spring of 1879 migrating in Dzungaria (Northern Xinjiang, China), on the Ulungur River, and in Southern Altai. The first arrivals were observed on the $15^{\text {th }}-27^{\text {th }}$ April, but the subspecies may have appeared a few days earlier, and in May it ceased to appear. This subspecies was also observed, apparently in autumnal flight, on Tuosu Lake in Tsaidam (Haixi Mongol and Tibetan Autonomous Prefecture, Qinghai, China) on $12^{\text {th }}$ September 1879 (Przewalski, 1887b), but this information is unreliable.

Sushkin (1914) observed the subspecies in small flocks on Lake Ulyungur (Fuhai County, Xinjiang, China) on $13^{\text {th }}$ April 1914.

In May 1926, Kozlova (1933) encountered leucocephala in migration near Orog Lake (Bayankhongor Province, Mongolia), and it was not a rare sighting, as their migration ended towards the end of May. On $4^{\text {th }} \mathrm{Au}-$ gust 1997, one adult and two juveniles (a possible family association) were in meadows $2 \mathrm{~km}$ west of Bjaruuchajnbulag (Byaruukhain Bulag) in Bordzongijn Gobi about 50 $\mathrm{km}$ south of Nomgon (Ömnögobi Province, Mongolia) (Stenzel et al., 2005).

In Kazakhstan, observations of the species were very sparse in the post-reproductive period: one individual was ringed at Alakol Lake on $8^{\text {th }}$ July 1981, and another was reported on Sorbulak Lake on $12^{\text {th }}$ September (Gavrilov \& Gavrilov, 2005). The white-headed yellow wagtail was more frequent in spring, especially in the Almaty Region, where the artisan well of Kanshengel Village (in the Taukum desert) is the best place to look for this rare passage migrant: one male on $10^{\text {th }}$ May 2003 (Gavrilov \& Gavrilov, 2005), one male on $7^{\text {th }}$ May 2007 (Ashby et al., 2012), five birds (including three males) on $9^{\text {th }}-12^{\text {th }}$ May 2007 (Hendriks, 2007; Kennerley \& Kovshar, 2007; Kovshar, 2012; Wassink \& Oreel, 2008), a male on $9^{\text {th }}$ May 2008 (Wassink, 2009a), one male on $9^{\text {th }}$ May 2009 (Central Asia Birding, 2009), and one first-summer male on $15^{\text {th }}$ May 2009 (Wassink, 2009b), one male on $10^{\text {th }}$ May 2014 (Vassiliy Fedorenko in birds.kz, 2019) and another one on $19^{\text {th }}$ May 2014 (Victoria Kovshar in birds.kz, 2019), one male on $6^{\text {th }}$ May 2015 (van der Woude, 2015), one or two males on $30^{\text {th }}$ April 2018 (Askar Isabekov in birds.kz, 2019) and one male on $6^{\text {th }}$ May 2018 (Alan Van Norman in eBird, 2019). Occasional presences were also recorded at the Sorbulak Lake system: one male on $1^{\text {st }}$ May 2006 (Belyalov \& Karpov, 2012), another one on $7^{\text {th }}$ May 2007 (Bird \& Annenkova, 2007), one on 22 ${ }^{\text {nd }}$ April 2012 (Gennadiy Dyakin in birds.kz, 2019), one male on $5^{\text {th }}$ May 2012 (Vassiliy Fedorenko in birds.kz, 2019), one on $28^{\text {th }}$ April 2013 (Vassiliy Fedorenko \& Aibek Adilmagambetov in birds.kz, 2019), one male on $9^{\text {th }}$ and $10^{\text {th }}$ May 2014 (Vassiliy Fedorenko in birds.kz, 2019; Ashby, 2014), one on $19^{\text {th }}$ and 29 $9^{\text {th }}$ April 2015 (Vassiliy Fedorenko in birds.kz, 2019), and one on $21^{\text {st }}$ and 29 ${ }^{\text {th }}$ April 2018 (Askar Isabekov in birds.kz, 2019). Isolated individuals were observed on $16^{\text {th }}$ and $20^{\text {th }}$ April 1988 in the Kopa Valley (Kovshar \& Berezovikov, 2018). At Alakol Lake, one male was photographed on $9^{\text {th }}$ May 2013 (Svetlana Aleinikova, Natalya
Borovaya and Askar Isabekov in birds.kz, 2019) and another one on $9^{\text {th }}$ May 2014 (Svetlana Aleinikova, Askar Isabekov and Valentin Zenkov in birds.kz, 2019). In the other regions of Kazakhstan, the subspecies appears only sporadically. In East Kazakhstan, one male was observed on $27^{\text {th }}$ April 2011 at Zhuzagash (Ayagoz District) (Gabor Papp in birds.kz, 2019) and another one was present on $7^{\text {th }}$ May 2011 in the same locality (Gabor Papp in birds. kz, 2019; Harrison \& Grieve, 2012a); on 13 ${ }^{\text {th }}$ May 2018, a male was photographed at Katon-Karagay National Park (Vorobyov, 2018). Otto Finsch saw light-headed yellow wagtails, probably of this subspecies, between the eastern end of Lake Zaissan and the Altai on $6^{\text {th }}$ June (Grant \& Mackworth-Praed, 1952). In the Karaganda Region, $M$. $f$. leucocephala was a rare passage migrant in northern Balkash Lake (Martin et al., 2018). In the Jambyl Region, the subspecies crossed the Chokpak Pass during spring migrations between $15^{\text {th }}$ April and $9^{\text {th }}$ May (Kolbintsev, 2001; Gavrilov \& Gavrilov, 2005); in autumn before the year 2001 , only one individual was recorded on $24^{\text {th }}$ September, and another one was observed on $6^{\text {th }}$ September 2001 (Kolbintsev, 2001; Gavrilov \& Gavrilov, 2005; Mary Gustafson in eBird, 2019). In the Kostanay Region, one male was recorded at Zorsu Lake on $16^{\text {th }}$ May $1997(30 \mathrm{~km}$ north of Kostanay) (Erokhov \& Berezovikov, 2009); two males were observed in groups with other western yellow wagtails near Burly (Karabalyk District) on $2^{\text {nd }}$ July 2016 (Yuri Malkov in birds.kz, 2019). In the Aktobe Region, Bostanzhoglo (1911) observed an individual on $15^{\text {th }}$ May at Lake Dzhumart-Kul near the scends of Bolshie Barsuki (between the Aral Sea and Shalkar city).

In Azerbaijan, a white-headed yellow wagtail was photographed at Besh Barmag (Syazan District) on $12^{\text {th }}$ April 2012 in a large flock of other western yellow wagtails including several subspecies, such as beema, lutea, thunbergi, flava and feldegg; it was the first record for the country (Harrison \& Grieve, 2012b; Heiss \& Eidam, 2015). An observation on $1^{\text {st }}$ May 2012 may also exist for the same locality (Azerbaijan Birding Data in eBird.org, 2019). A white-headed individual was photographed in the first half of April 2018 in Western Azerbaijan (Baumgarten, 2018). There is also a record at Alazan delta (Samukh District) on 20 ${ }^{\text {th }}$ April 2018 (Zulfu Ferecli in eBird.org, 2019), but we have not found photographic documentation of this specimen.

In the Middle East, the leucocephala subspecies was a vagrant in North-Eastern Iran, Turkey, Israel, Kuwait, and the United Arab Emirates (Alström et al., 2003; Porter \& Aspinall, 2010; Kirwan et al., 2014; Eriksen \& Porter, 2017).

In Iran, in the past the subspecies was reported in the north-east of the country (Southern Khorasan and Paropamisus) (Zarudny, 1911). A western yellow wagtail with a whitish head was observed in the Maranjab Desert (Isfahan Province) on 13 ${ }^{\text {th }}$ April 2013 (Klunderud, 2013), but this record was not included in the recent Iranian Checklist of the Species and Subspecies (Khaleghizadeh et al., 2017). One male was photographed by Siavash Roshanian at Incheh wetland, Aq-Qala (Golestan Province) on $7^{\text {th }}$ April 2017 (Iran Bird Records Committee, 2019). 
In Turkey, a male was observed in the south Van marshes (Eastern Anatolia Region) on 25 ${ }^{\text {th }}$ April 2011 (first record for the country) (Kirwan et al., 2014).

In Israel, Joop Swaab observed an individual at Eilat in April 1980, and a male was observed by Alon Bear, Yaron Baser, and Ehud Dovrat at Shifdan on $7^{\text {th }}$ April 1984. This bird, however, showed signs of being a hybrid (e.g. yellow back and white head) (Shirihai, 1996). It is considered rare in the spring (Yardbirds, 2020).

In Kuwait, the white-headed yellow wagtail was a rare passage migrant with presences usually reported between mid-April and mid-May (Al-Sirhan, 2009; 2010; 2018; Pope \& Zogaris, 2012). A male was photographated on $20^{\text {th }}$ April 2008 at Jahra East Outfall (Fågel, 2008).

In the United Arab Emirates, an individual attributed to leucocephala subspecies was at Dubai pivot fields on $11^{\text {th }}$ April 2003 (the first record of this subspecies) (Balmer \& Betton, 2003). An individual was observed at Abu Dhabi Bateen Park on $25^{\text {th }}$ and $26^{\text {th }}$ March 2005 (Balmer $\&$ Betton, 2005) and an adult male was at Abu Dhabi Golf on $8^{\text {th }}-11^{\text {th }}$ April 2006 (Balmer \& Betton, 2006). Pedersen and Aspinal (2010) highlighted the possible confusion with intraspecific hybrids between lutea and beema.

In Oman, until $6^{\text {th }}$ March 2017, only two records were known (one in May) (Eriksen, 2017; Eriksen \& Porter, 2017).

There were also some reports for South-Eastern Europe, but without photographic documentation: a western yellow wagtail with a light head was observed, along with hundreds of individuals of flava and feldegg subspecies, at Paphos (Paphos District, Cyprus) on $13^{\text {th }}$ April 2016 (Stylianou, 2016), but leucocephala was not included in the list of subspecies accepted for this island (Richardson \& Porter, 2020); in Greece, two birds similar to leucocephala were observed in May 1960 and May 1961 in the north-east (Raines, 1962; Bauer et al. 1969; Handrinos \& Akriotis, 1997) and a very white-headed bird that resembled a white-headed yellow wagtail was observed on $14^{\text {th }}$ April 2017 at Frangokastello (Chania, Crete) (Willsher \& Willsher, 2017); in Italy, a western yellow wagtail with a white head was observed in a reed bed roost site at Mirandola (Emilia-Romagna Region) on $18^{\text {th }}$ April 2002 (Giannella \& Tinarelli, 2003).

In Africa, Ramsay (1923) stated that the leucocephala was a migrant in Egypt, but he did not provide detailed information and Nikolaus (1983) considered it a migrant and winter visitor in Sudan, but cited a single observation made in February along the Red Sea.

In Eritrea, the white-headed yellow wagtail was a relatively scarce passage migrant, but it was not a winter visitor (Ash \& Atkins, 2009).

In Ethiopia, the subspecies was reported in the Oromia Region: one individual in March 1971 and two individuals in March 1972 were at the Koka Reservoir (Ash \& Atkins, 2009; Gedeon et al., 2017); three birds were at Addis Ababa Bole International Airport on $27^{\text {th }}$ February 2017 (Akash Gulalia in eBird.org, 2019).

Van Someren (1931) claimed that specimens with white heads were obtained from eastern Uganda and Kenya in November and $21^{\text {st }}$ April. In Uganda, an observation of the subspecies leucocephala was reported in Entebbe (Central Region) on $4^{\text {th }}$ April 1967 (Pearson, 1972; Britton, 1980; Pearson \& Turner, 1986). In Kenya, specimens showing the characteristics of the whiteheaded yellow wagtail were captured in the Nairobi area (Reynolds, 1974). An individual was seen at Solio Ranch (Laikipia County, Rift Valley Province) on $16^{\text {th }}$ April 2009 (AfricanBirdClub, 2010), another one was observed on $1^{\text {st }}$ March 2017 in Kiambu County (Central Province) (Samira Khan in eBird.org, 2019); a bird was present on $14^{\text {th }}$ April 2017 at Amboseli National Park (Kajiado County, Rift Valley Province) (Ellen Miller and Michael Weaver in eBird.org, 2019), and three individuals were at Lake Nakuru National Park (Nakuru County, Rift Valley Province) on 23 $3^{\text {rd }}$ March 2019 (Sally Pfeiffer and Doug Pfeiffer in eBird.org, 2019).

In Tanzania, one male was recorded on March 2006 at Manyara Lake (Arusha and Manyara regions) (Beaman \& Jännes, 2008) and two males were photographated on $5^{\text {th }}$ April 2015 at Ngorongoro Crater Rim (Arusha Region) (Holmen, 2015). Keith et al. (1992) also cited the locality of Arusha Chini (Moshi Rural District), but the date of the observation is not known.

In Malawi, one specimen was captured on $26^{\text {th }}$ March 1947 at Karonga (Northern Region) (Benson, 1951; Williamson, 1955; Constantine \& Benson, 1977).

In Zambia, there was only one record near Luangwa (Lusaka Province), but Constantine (1971) did not specify the date. According to Grant and Mackworth-Praed (1952), a western yellow wagtail was captured at Kanyani, Northern Rhodesia (today part of Zambia), on $3^{\text {rd }}$ March 1905 and doubtfully classified as a beema, was instead a leucocephala.

In China, the white-headed yellow wagtail was found in the Junggar Basin (Xinjiang) during the migration (Zhengjie, 2009; CASD, 2019; Weiwenku.org, 2019). The subspecies was recorded at Ebi Lake (Bortala Prefecture) (XIEG, 2011) and ten individuals were observed in the Ili River Wetland (Ili Kazakh Autonomous Prefecture) in late summer 2016 (Huang Ya-dong et al., 2009).

In Pakistan, a male was captured by Hugh Whistler on $2^{\text {nd }}$ May 1913 at Jhelum (Punjab Province); it was the only one of its kind seen, and was migrating in company of many M. f. beema (Ticehurst, 1915; Whistler, 1916; Baker, 1926). On 27 th April 1938, Waite (1939) spotted a male from amongst a number of $M . f$. beema on a passage near Chhoi in Campbellpore (Attock District, Punjab Province). On $25^{\text {th }}$ April 1939, five males were collected at Malpur (Rawalpindi District, Punjab Province) and on $10^{\text {th }}$ May 1939, a male was observed at Khanna (Rawalpindi District, Punjab Province) (Whistler, 1940). In April 1940, 17 specimens were collected in the Rawalpindi District (Punjab Province) (Waite, 1962). Roberts (1992) stated «... is distinctly rare and only occurs for a brief period on spring passage when it can be encountered in the Potohar, Salt Range and around Jhelum, and Attock (Campbellpur) districts. Both $\mathrm{H}$. Whistler and $\mathrm{H}$. Waite collected a good series of specimens from these between 18 April and 10 May (Brit. Mus., Tring). The author has seen several individuals in full breeding dress on 4 May in company with large numbers of thunbergi on the shores of Rawal lake.». Grimmett et al. (2008) confirmed that Rawal Lake (Is- 
lamabad Area) was a good place to see the white-headed yellow wagtail. The leucocephala was also observed in the metropolitan areas of Rawalpindi and Islamabad (Yousuf et al., 2015). The subspecies was reported in the Swat Valley (Government of Khyber Pakhtunkhwa, 2013), and it was included in the Jammu and Kashmir birds check list (Department of Wildlife Protection, Govt. of Jammu and Kashmir, 2011). Even recently, the subspecies has been confirmed as a passage migrant (Murtaza \& Ahmed Khan, 2010; Yousuf et al., 2015; Manzoor et al., 2017; PMDNDMA, 2019) and winter visitor in Pakistan (Fakhar Abbas \& Madeeha Manzoor, pers. com.; Mirza, 1998; PMDNDMA, 2019).

The leucocephala subspecies was included among those observed in Nepal, but we did not find detailed data (Shrestha, 2001; Grimmett et al., 2016; Inskipp et al., 2016).

In India, a male was observed on $11^{\text {th }}$ April 1965 alongside the Agra Canal, near Delhi, during an intense western yellow wagtail migration (Jackson, 1965). Strangely, the data was not reported in the book of Ganguli (1975) dedicated to birds in the Delhi area. A single male was observed in a flooded stubble field near the western Yamuna Canal, between Tihara and Malhala villages, in the Sonipat District (Haryana) on $10^{\text {th }}$ January 2003 (Sharma, 2005). An individual was recorded at Okhla Bird Park, South-East of Delhi, on 12 $2^{\text {th }}$ April 2009 (Anand Arya in orientalbirdimages.org, 2019) and one was present on $11^{\text {th }}$ April 2009 at Dadri (Uttar Pradesh) (Subhashc in iNaturalist.org, 2019). In Rajasthan, the presence of individuals attributed to leucocephala was recorded: at Jawai Dam, near Pali (Marwar Region) on 22 $2^{\text {nd }}$ March 2015 (Lloyd Fernandes in eBird.org, 2019), at Bikaner (Bikaner Region) on $9^{\text {th }}$ September 2017 (Partap Kataria and Raja Bandi in eBird.org, 2019), and at Churu (Bikaner Region) on $31^{\text {st }}$ January 2019 (Gajendra Tanwar in eBird.org, 2019). In West Bengal, a male of the subspecies was photographated at Boshipota on $27^{\text {th }}$ February 2011 (Das, 2011). In Assam, the white-headed yellow wagtail was migrant and wintering (Deka et al., 1996); between $10^{\text {th }}$ and $27^{\text {th }}$ April 1950, 18 specimens were captured at Phulbari (Lakhimpur District) and their skins are now preserved in the Museum of Zoology of the University of Michigan (University of Michigan Museum of Zoology, 2019). In Arunachal Pradesh, one individual was observed at Mandala Road (West Kameng District) on 12 ${ }^{\text {th }}$ May 2018 (Geetha Venkataraman and Sudeshna Dey in eBird.org, 2019). In Maharastra, a few were recorded during the period from 2011-2013 near Solapur (Raghvendra et al., 2014). In Kanataka, a male was photographated at Hoskote Lake (Bangalore Rural) on $8^{\text {th }}-9^{\text {th }}$ April 2017 (Jayadevan et al., 2018), and in the same place another male was recorded on $24^{\text {th }}$ and $31^{\text {st }}$ March 2019 (Dipu Karuthedathu, Krishna Murthy, J. Praveen, and Tejas Praveen in eBird.org, 2019). In Andhra Pradesh, the subspecies was common in winter between 2007 and 2012 at Kolleru Wetland, but it seems strange that no other subspecies were present (Vasudeva Rao et al., 2014).

In Sri Lanka, until 1998 the subspecies was not known for the island (Henry, 1998), but an individual attributed to leucocephala was observed at Sevanagala (Monaragala
District, Uva Province) on $2^{\text {nd }}$ December 2018 (Benny Cottele in Observation.org, 2018).

Exceptionally, the subspecies was also observed in Japan. In the Tokara Islands (Kagoshima Prefecture) on $3^{\text {rd }}$ May 1988 and $3^{\text {rd }}$ May 2011, one bird was observed and photographed by Hirashima (Tokorozaki, 2011; Ikenaga et al., 2014). Erratic movements in the Far East are also known for other subspecies of the western yellow wagtail: on $13^{\text {th }}$ May 2013 a Motacilla flava feldegg was observed in Beijing at Lake Shahe (Townshend, 2013), and an individual of Motacilla flava beema was observed in Japan at Takahama (Nagasaki) on $6^{\text {th }}$ May 2014 (Ikenaga \& Yanagisawa, 2015). In addition to the greater ease of identification of subspecies of western yellow wagtail, the reports in spring of individuals exceptionally east from their usual migration routes is probably related to the winds that cross the highlands of Central Asia from west to east and that can "drag" the small passerines (Bolshakov, 2003).

\section{Other pale-headed wagtails}

Western yellow wagtails with white or very pale heads were recursively observed during breeding season in the Volga Valley, in the territories of the Ulyanovsk Oblast and the Chuvash Republic. In the Ulyanovsk Oblast, individuals with a "pale head" performing nesting behavior were recorded near Ulyanovsk city (Zavolzhye, Kulikovka, June 2012), in the Ulyanovsky District (Barataevka village, on $18^{\text {th }}$ June 2013) and in the flat meadows in three Trans-Volga districts (Staromaynsky, Cherdaklinsky - on $7^{\text {th }}$ June 2013 at Cherdakly - and Melekessky - on $31^{\text {st }}$ May 2016, surrounding the city of Dimitrovgrad), especially along the coast of the Kuibyshev reservoir (Moskvichev, 2013a; 2013b; 2013c; Oleg Borodin, AndreyMoskvichev and Natalya Neverovain in volgabirds.ru, 2019). A male with a pale head was at Cherdakly (Cherdaklinsky District) in May 2013 and May 2014 (Artemyeva, pers. com.), and a male with a white head was photographed by Tatyana Kezhevatova (pers. com.) on 31 May 2016 at Kulikovka (Melekessky District). In the Chuvash Republic, the presence and nesting of wagtails with white or very pale heads were documented in the Ibresinsky District in summer 2011 and 2012 (Artemyeva \& Muravyev, 2012a; 2012b; Yakovlev et al., 2012).

In the past, Sushkin $(1925 \mathrm{c})$ found a breeding individual with a white head on the Belaya River, about 40 $\mathrm{km}$ north of Ufa (Republic of Bashkortostan).

Near Gorny Shchit carp fish factory ponds (Yekaterinburg, Sverdlovsk Oblast) an individual with a completely white head was observed on $6^{\text {th }}$ July 2013 (Reshetkova, 2013).

A specimen with pale head collected on $12^{\text {th }}$ June 1843 at Lake Bulukhta (Pallasovsky District, Volgograd Oblast) is preserved in the Zoological Institute of the Russian Academy of Sciences (Saint Peterburg).

A specimen was collected in the Zhanakala District (West Kazakhstan Region) on $25^{\text {th }}$ April 1862, and it is preserved in the Zoological Institute of the Russian Academy of Sciences (Saint Peterburg). Sushkin (1914), talking about Motacilla flava leucocephala, stated «... in the Chaikar District regularly breeding.»; the Chaikar District 
roughly coincides with the current Mugalzhar District (Aktobe Region, Kazakhstan). Western yellow wagtails with pale heads were observed in May 1915 near Aktobe (Aktobe Region, Kazakhstan) (Karamzin, 2003). Sushkin (1925c) found a breeding individual with a white head in the basin of Turgai River near Amangeldi (Kostanay Region, Kazakhstan).

In analogy with what was observed in northern France where the mixed couples M. f. flava and M. f. flavissima generate pale-headed intergrades colloquially known as channel wagtail (Dubois, 2001; 2007), the individuals with white or very pale heads observed in the previous russian and kazakhs areas were first generation intraspecific hybrids between $M$. f. lutea and M. f. beema (Sotnikov, 2006; Artemyeva \& Muravyev, 2012a; 2012b; Redkin, 2013). In the Ulyanovsk Oblast and Chuvash Republic, in the breeding season, the flava subspecies was largely dominant, with a marginal presence of beema, while in Asian Russia and Kazakhstan beema was prevalent (Moskvichev et al., 2011; Artemyeva et al., 2013; Muravyev, 2013). In almost all of these locations the lutea subspecies was present with very low densities; in European Russia, the density in the previous districts of the Ulyanovsk Oblast and Chuvash Republic was 1-10 nesting pairs in squares of $50 \times 50 \mathrm{~km}$, while in the same areas the other subspecies have an overall density ten times or even a hundred times higher (Muravyev \& Artemyeva, 2012; 2016; Artemyeva et al., 2013; 2014; 2015a; 2015b; Korepov \& Korepova, 2013; Moskvichev, 2013b; 2013c; 2013d; Korepov et al., 2014; Nikiforova, 2015; Lebedeva, 2017). The same situation (with beema instead of flava) also occurred in Asian Russia and Kazakhstan. Probably the difficulty for lutea to finding partners of its subspecies favors the establishment of mixed couples.

Wagtails with a white head also appeared in completely unexpected places. The best known case was the English one; an individual (now in the British Museum) attributed to the leucocephala subspecies was feeding flying young when it was spotted by C. B. Ticehurst at Wittersham (Kent County) on $19^{\text {th }}$ June 1908 (Williamson, 1955). This record was reviewed by the BOU List Committee in 1949 as M. f. beema together with five other specimen records of beema and all six were considered to be $M$. f. flava (British Ornithologists' Union Records Committee, 2007). A bird apparently similar to leucocephala was observed near Colonia (Germany) in summer 2014, but after examination of photographs of the bird in flight, it emerged that it was leucistic (the eighth primary on each wing was white) (Gray, 2014). A wagtail showing a whitish head (with some dark grey tinge) and broad wing bars was observed from $28^{\text {th }}$ to $31^{\text {st }}$ March 2019 at Lut Chau (Hong Kong), but considering also its call, it most likely was a leucistic eastern yellow wagtail (Birding Hong Kong, 2019; ovingthetodiesforever.blogspot.com, 2019). On $1^{\text {st }}$ May 2019, a possible white-headed yellow wagtail was discovered by Haiming Zhao at Cape Nanhui (Shanghai, China), but the bird had a mottled mantle and scapulars and a pale basal to the lower mandible, thus also in this case it was not possible to attribute the specimen with certainty to the leucocephala subspecies (Shanghai Birding, 2019).

\section{DISCUSSION}

\section{Breeding habitat and range of Motacilla flava leucocephala}

Breeding ecology of the subspecies is not well documented. Major references (Dawaa et al., 1994; Fomin \& Bold, 1991; Gombobaatar et al., 2011; Gombobaatar \& Leahy, 2019) on birds in Mongolia have not mentioned the breeding ecology of this subspecies. However, these references pointed out that this subspecies occurs and breeds in open valleys of large lakes in the Great Lakes Depression (west Mongolia). The data collected in this study confirm this indication (Fig. 7).

The Great Lakes Depression is a semi-arid depression bordered by mountains: Mongol-Altai in the west, Tannu-Ola in the north, Khangai in the east, and Gobi-Altai in the south. The depression is $600-650 \mathrm{~km}$ in length with a width of 200-250 km in the north and 60-100 km in the south with a total area of about $186,600 \mathrm{~km}^{2}$ (Borodavko, 2009). The elevation of the basin floor is from $1,700 \mathrm{~m}$ a.s.l. to $760 \mathrm{~m}$ a.s.l., decreasing to the north and southeast. The maximum elevation of the mountains is 4,000 $\mathrm{m}$ a.s.1.; there are some mountains with an elevation between 2,000 and 3,000 $\mathrm{m}$ a.s.l in the lake catchment (Borodavko, 2009). The depression contains six major lakes of Mongolia: saline Uvs Lake, Khyargas Lake, and Dörgön Lake; and freshwater Khar-Us Lake, Khar Lake, and Airag Lake, as well as a number of smaller lakes and various sized ponds and other wetlands (Tserensodnom, 1971; Tarasov et al., 1994). In addition, it includes $14,000 \mathrm{~km}^{2}$ of solonchaks and large sandy areas. The major rivers are Khovd, Zavkhan, and Tes. The terraced lake shores are covered by steppe and desert vegetation. Pharagmites $s p$. is abundant in the river deltas and close to the shore-line and the shallow-water littoral is covered by rich aquatic vegetation, including Myriophyllum verticulatum, Zannichelia pedunculata, and Utricularia vulgaris (Sevastyanov et al., 1994). Some lakes in the Great Lakes Depression with vast reed beds (some of the last remaining in Central Asia) create a unique ecosystem. The sharp contrast of high mountains and steppe and the desert steppe bordering the diverse wetlands creates a highly distinct landscape. The subspecies is also present at Achit Lake and its surrounding wetlands, in the Mongol-Altai Range. The Achit Lake is a freshwater lake lying in an intermountain basin at 1,435 $\mathrm{m}$ a.s.l. and it is connected to the Khar-Us Lake, in the Great Lakes Depression, through the ecological corridor constituted by the course of the Khovd River. All these lakes are included in the Mongolian Plateau: the Inner Mongolia Autonomous Region of China and the entire territory of Mongolia constitute its core region, with an area of about 2.75 million $\mathrm{km}^{2}$ (Sneath, 1998; National Statistical Office of Mongolia, 2008). In the plateau, a number of lakes have shrunk remarkably in recent decades as a result of intensive human activities and climate change (Tao et al., 2015). The number of lakes with a water surface area $>1$ $\mathrm{km}^{2}$ decreased from 785 in the late 1980 s to 577 in 2010 , with a greater rate of decrease $(-34.0 \%)$ in Inner Mongolia of China than in Mongolia (17.6\%). The statistical analyses suggested that in Mongolia precipitation was the 


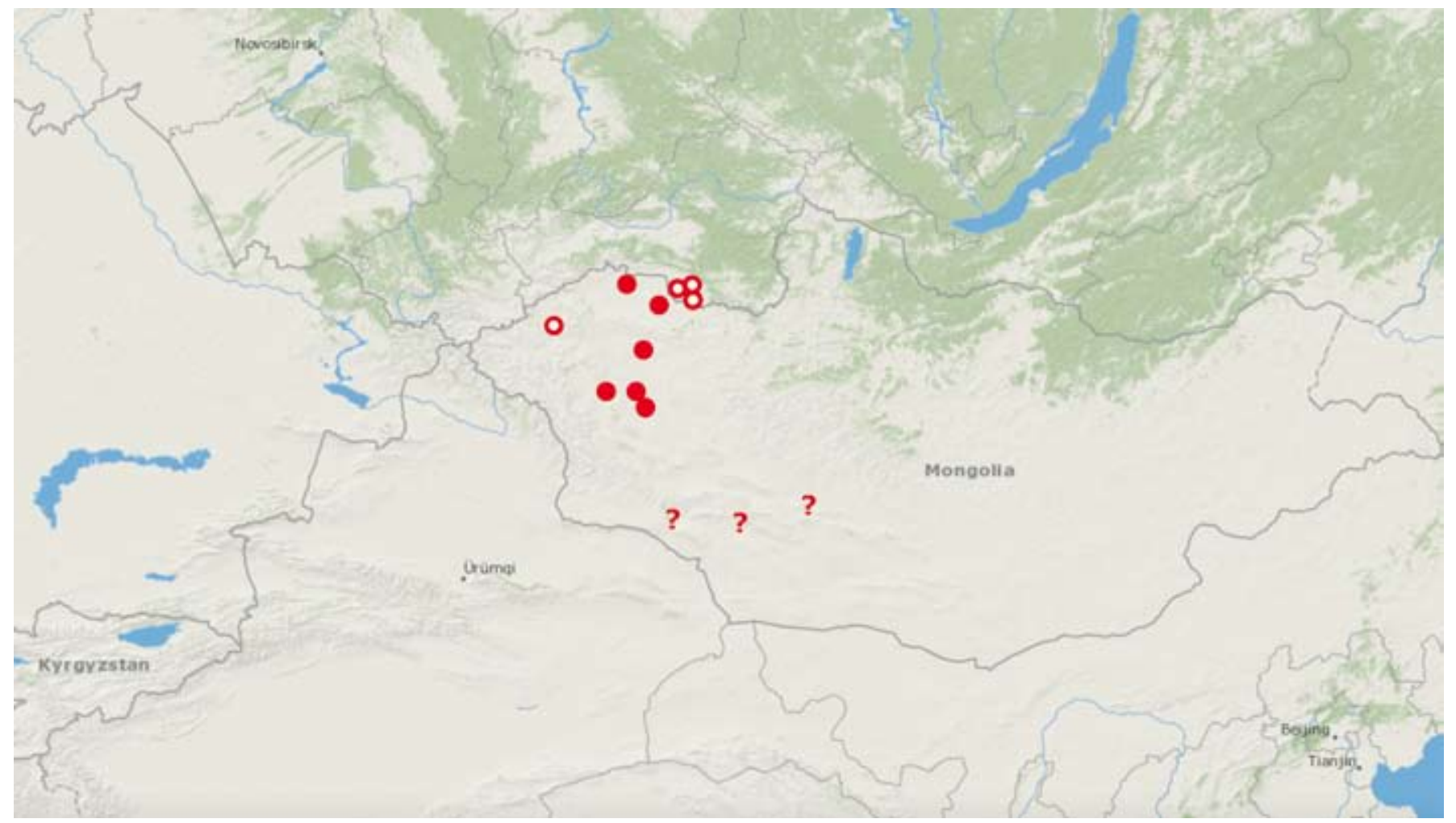

Fig. 7 - Breeding sites of Motacilla flava leucocephala. / Siti di riproduzione della Motacilla flava leucocephala. Breeding site with the presence of only M. f. leucocephala. / Areali di riproduzione con la sola presenza di M. f. leucocephala. $\odot$ Breeding site with the presence of M. f. leucocephala, M. f. beema, and intraspecific hybrids leucocephala x beema. / Areali di riproduzione con la presenza di M.f. leucocephala, M. f. beema e ibrido intraspecifico leucocephala x beema. ? Presence in breeding season without evidence of nesting. / Presenza nella stagione riproduttiva senza evidenza di nidificazione.

dominant driver for the lake changes (Tao et al., 2015). Fortunately for the leucocephala and for threatened species nesting only in the aquatic environments of Western Mongolia (e.g. white-headed duck Oxyura leucocephala and dalmatian pelican Pelecanus crispus), until 2010 the lakes of the Great Lakes Depression, as well as those in the Mongol-Altai Mountain Range, had shown no signs of contraction, while further south, in the Valley of the Lakes, the surface of Böön Tsagaan Lake had decreased by $14.2 \%$ in 1990-2010, and the Orog Lake dried up in August 2009 (Tao et al., 2015). The lakes of this last geographical area have been repeatedly visited in breeding season without observation of the white-headed yellow wagtail (Bâlon \& Burban, 2008; Dufourny, 2010; Kehoe \& Khayankhayrvaa, 2014; Rockjumper, 2016; Van Beirs \& Khayankhayrvaa, 2016; Oláh et al., 2018). This suggests that French's observation in early June 2018 and late May 2019 (pers. com.), as well as that of Kozlova's (1933) on $7^{\text {th }}$ June 1926 were attributable to late migrants. However, considering also the presence of couples and other individuals in late June in wetlands in the GobiAltai Province (Dubois, 2016), the possible nesting of the subspecies in the Gobi-Altai Mountain Range and in the Valley of the Lakes (south-west Mongolia) should be further investigated.

The northernmost reproductive area occupied by the leucocephala is the flat southern part of the Tuva Republic (Russian Federation) between the Oruku-Shina and
Kosh-Terek rivers (Fig. 8), but it should be pointed out that Sushkin (1925c) explicitly excluded the presence of the subspecies in the Uvs Lake Basin in the early decades of the $20^{\text {th }}$ century and Dementiev and Gladkov (1954) did not include the leucocephala among the subspecies of western yellow wagtail that nested until the 1950s in the Soviet Union and indeed explicitly stated that its breeding range included only north-west Mongolia. The white-headed yellow wagtail therefore began to expand its breeding range into Russian territory only from the beginning of the second half of the $20^{\text {th }}$ century (Vaurie, 1959; 1960). The northern expansion of the breeding range is also common to other subspecies of the western yellow wagtail both eastward (feldegg and lutea) (Ferlini, 2016; Ferlini \& Artemyeva, 2020), and westward (cinerocapilla) (Ferlini, 2015) and is probably related to ongoing climate change.

The subspecies beema also arrived in the same area, but probably at a later date. The situation is well summarized by Redkin (2011): «Judging from our collections and field observations, as well as from the results of studying the collection materials of ZMMGU and ZIN, only phenotypically pure beema populations nest in the Turan and Kyzyl basins. In the south of Tuva (south of the Tannu-Ola ridge), the situation is more complicated and requires special commentary. For primary researchers and us the nesting of yellow wagtails was established along the shores of lakes Ubsu-Nur, Shara-Nur and Tore-Khol. 


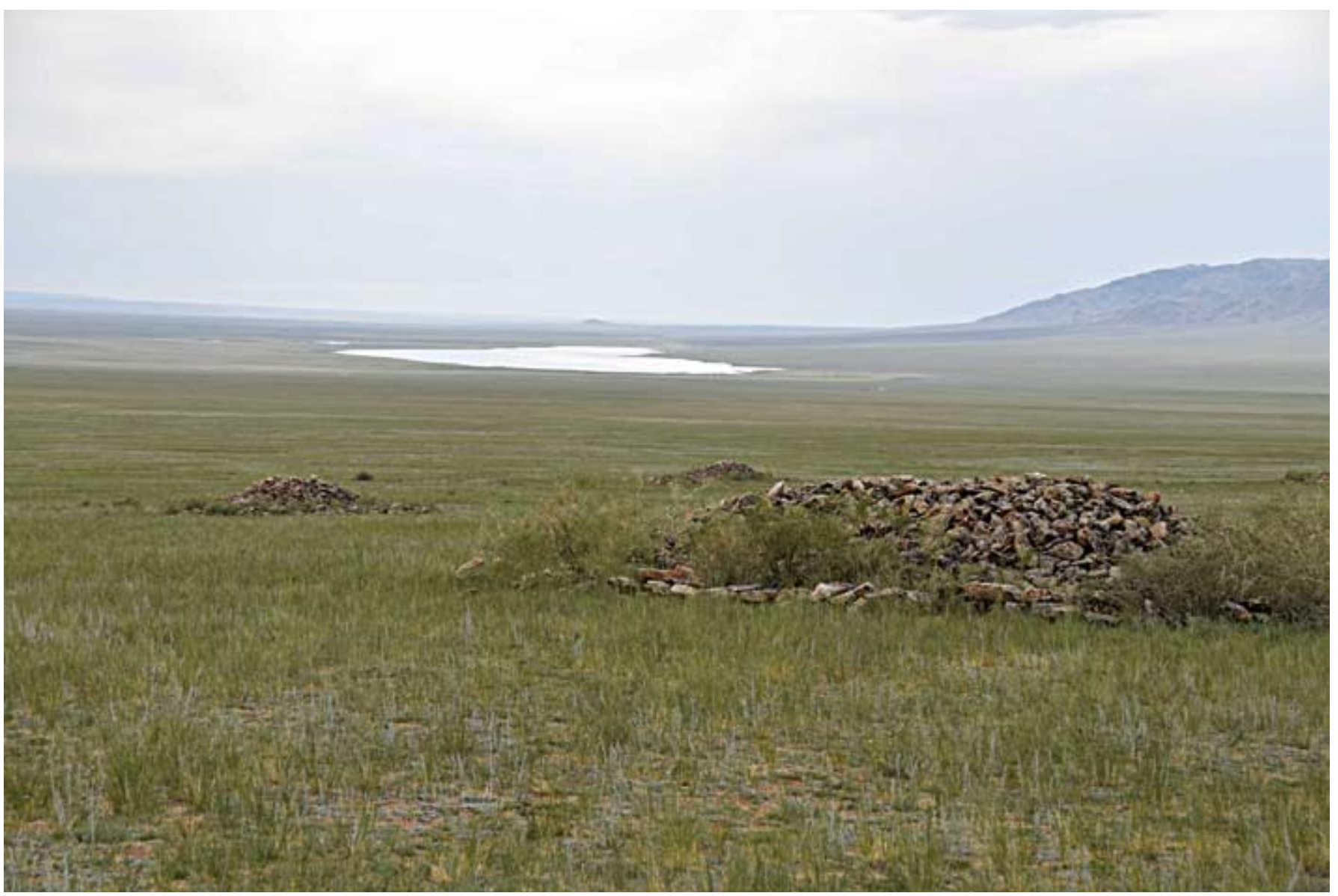

Fig. 8 - Salt-saucer lakes in the Uvs Nuur Basin in Mongolia and Russia are potential breeding sites for Motacilla flava leucocephala, $7^{\text {th }}$ December 2015. / I laghi salati nel bacino del lago Uvs Nuur (Mongolia, Federazione Russa) sono potenziali siti di riproduzione per Motacilla flava leucocephala, 7 dicembre 2015. "Saucer Lakes will point the way / The green grass will shine. / Spring in April will come to us, / And the birds on the wings will bring!". / "Saucer Lakes indicherà la strada / L'erba verde brillerà. / La primavera in aprile verrà da noi, / E gli uccelli sulle ali la porteranno!" (Verse by / Versi di: Elena A. Artemyeva). (Photo / Foto: Dmitry Grudinin).

During our studies in 1999-2000, mixed settlements were found in all three points, represented by individuals of the pure phenotypes of each of the forms under discussion, and by a fairly large number of specimens with intermediate characteristics. It is noteworthy that from collection materials (ZMMGU) and visual observations of V.Yu. Ilyashenko (Redkin, 2011), in 1987-1989 in the same points nested only leucocephala. At the same time, we studied a specimen of a male collected in the summer 1980 on Lake Ubsu-Nur, which had intermediate characteristics between leucocephala and beema (CGPGU). These circumstances suggest the irregular nesting of bee$m a$ outside the source nesting area (south of East TannuOla) together with the white-headed form leucocephala. At the same time, the level of hybridization of these forms is quite high.». Of the 60 specimens collected at the UbsuNur, Shara-Nur, and Tere-Khol lakes in 1999 and 2000, $45.0 \%$ were attributable to the phenotype leucocephala, $18.3 \%$ to beema and $36.7 \%$ to leucocephala $\mathrm{x}$ beema intraspecific hybrids (Redkin, 2011).

After reporting the presence of the leucocephala subspecies at Achit Lake in 1911 and 1914, Sushkin (1938) stated: «... there are no other representatives of B. flava, and there are generally no yellow wagtails in this area, but only in a small amount of M. citreola.». Today, however, we know that the subspecies beema already occupied this area in 2007 and that, mating with leucocephala, it generated individuals with intermediate traits between the two subspecies (Hellström, pers. com.; Malmaeus, 2007). Individuals with intermediate traits were also present at Achit Lake in June 2017 (Hellström, 2017). During the last few years, beema has been observed in the reproductive period also at the Khar-Us Lake (Silas Olofson, pers. com.) and it is therefore foreseeable that also in this area an intraspecific hybridization process may begin.

The data collected do not confirm the breeding of the white-headed yellow wagtail in the north-eastern part of China (Xinjiang). During visits and research carried out in reproductive period in areas potentially suitable for the presence of lakes (e.g. Sayram Lake in Bortala Prefecture, Ulungur and Kanas lakes in Altay Prefecture) in the northern part of Xinjiang, the leucocephala subspecies has never been encountered (only sporadically observed M. f. feldegg of the form melanogrisea which here reaches the farthest east of its breeding range) (Kilburn, 1998; Ferlini, 2016; Brelsford, 2017; Dev, 2018; Liu Xu, 2018). 


\section{Migratory movements and wintering range of Motacilla flava leucocephala}

Though the white-headed yellow wagtail has a reproductive range confined to the heart of the Asian continent and is of limited size when compared with those of the other four asiatic subspecies (lutea, beema, feldegg and thunbergi) that extend from Eastern Europe to Central Asia, it has wintering ranges that are disjointed in Asia and Africa (Fig. 9).

Based on the number of reported birds (sometimes also groups), the Indian subcontinent hosts the majority of the leucocephala population in winter. The individuals seem to be distributed mainly in the northern and eastern part of India and in Pakistan (probably in the north-eastern part), as already hypothesized by some authors (Ali \& Ripley, 1987; Grimmett \& Inskipp, 2003). In the same area, individuals with intermediate characteristics leucocephala $\mathrm{x}$ beema, generated by mixed couples in the Tuva and Achit Lake area, should also appear. The presence of the whiteheaded yellow wagtail in Sri Lanka should be confirmed and documented, as the island is one of the wintering areas favored by the lutea subspecies, so here, as in the rest of the subcontinent, there is the possibility of confusing leucocephala with intraspecific hybrid lutea $\mathrm{x}$ beema with a very pale head.
On the basis of spring observations, it would seem that the birds, when embarking on the journey to the north, avoid crossing the complex deserts and mountains of the Tibetan Plateau still largely covered in snow and bypass it to the west. Similarly to what has been observed for other passerines (Dolnik, 1990; Bolshakov, 2001; 2003; Irwin \& Irwin, 2005), the white-headed yellow wagtail reaches the southern slopes of the Himalayas and follows its trend towards the north-west until it meets the Hindu Kush mountain range. Given the relative frequency with which the subspecies is reported in the Rawalpindi and Islamabad areas, it is possible that crossing Hindu Kush takes place at the point of least amplitude, perhaps using the Khyber Pass and the other passes not far from Kabul. Once past this barrier, it is not clear what path is followed, as there are no signs for a long stretch. However, it is known that after crossing Hindu Kush, about $15 \%$ of passerines turn north-east and cross the western part of the Tien Shan, while 85\% turn north-east only after reaching the deserts around the 39th parallel North (Bolshakov, 2003; Irwin \& Irwin, 2005; Newton, 2008; Rasmussen \& Anderton, 2012). The point where the subspecies regularly passes in spring is the Chokpak Pass (between $15^{\text {th }}$ April and 9 th May) (Kolbintsev, 2001; Gavrilov \& Gavrilov, 2005)

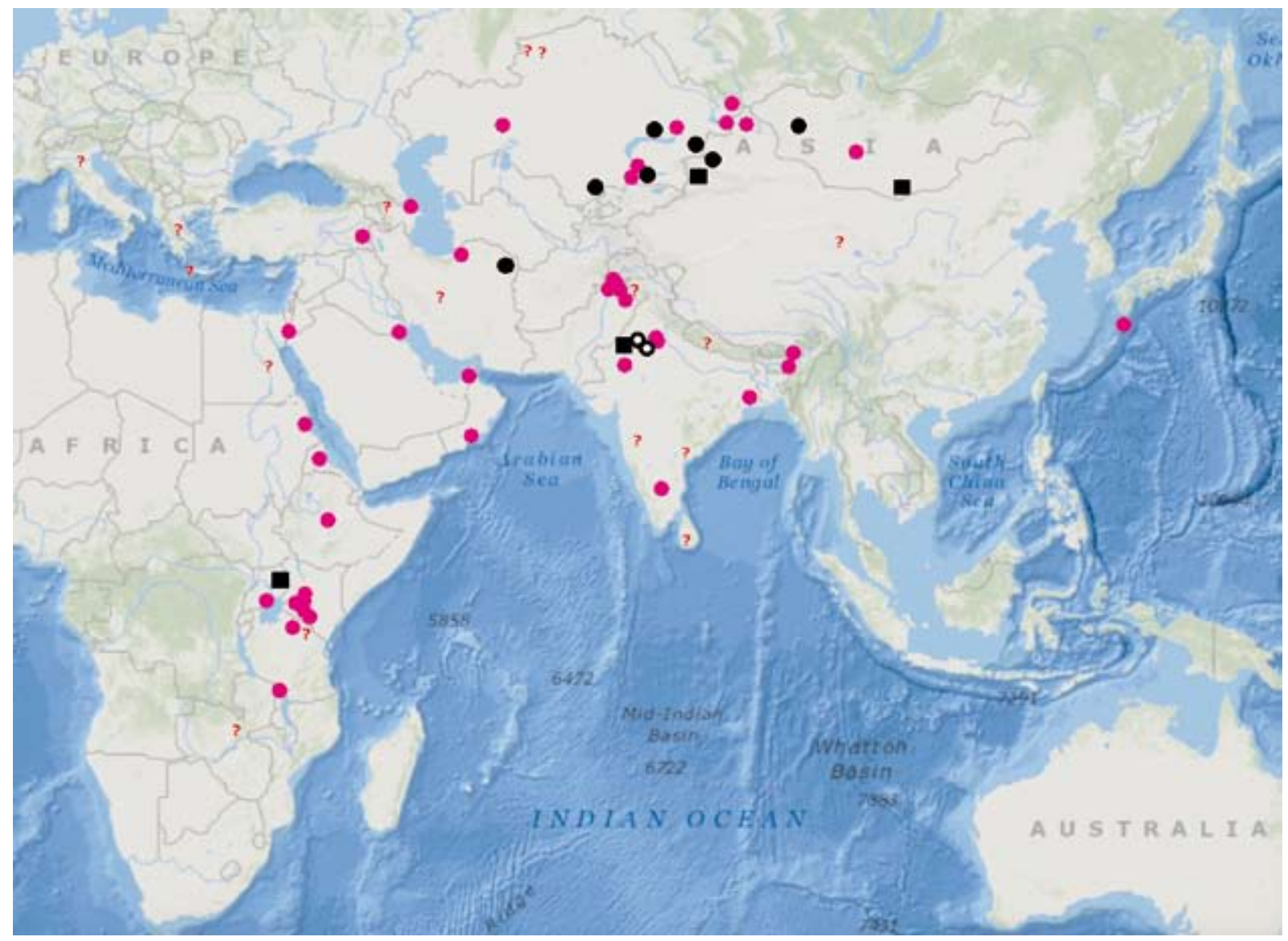

Fig. 9 - Migratory movements and wintering sites of Motacilla flava leucocephala. / Movimenti migratori e aree di svernamento della Motacilla flava leucocephala. Site with M. f. leucocephala presence in spring. / Sito con presenza in primavera di M.f. leucocephala. - Site with M.f. leucocephala presence in autumn. / Sito con M. f. leucocephala presente in autunno. Site with M. f. leucocephala presence in spring and autumn. / Sito con M. f. leucocephala presente in primavera e autunno. $\odot$ Site with $M$. $f$. leucocephala presence in winter (December-January). / Sito con M. f. leucocephala presente in inverno (Dicembre-Gennaio). ? Site with uncertain data. / Sito con dato incerto. 
through which it reaches the Taukum desert, the Sorbulak Lake system, the Alakol Lake, and also the East Kazakhstan Region. The reproductive area is probably reached by crossing the Junggar Basin (Xinjiang) and then the Altai Mountain.

The autumn migration probably occurs following routes similar to the spring ones, although it is possible that, in analogy to other passerines, the mountains are partially crossed as they are less inhospitable than during the spring period (Dolnik, 1990; Bolshakov, 2001; 2003; Irwin \& Irwin, 2005; Newton, 2008).

A minority fraction of the leucocephala population in autumn heads west along the Great Rift Valley Flyway (probably single individuals herded with members of other subspecies) to reach and winter in Equatorial East Africa (Kenya, Uganda, Tanzania, northern Malawi, and, to be reconfirmed, Zambia) (Ferlini, 2020). In the spring, migration follows the Rift Valley (February - early-April) in a northerly direction in Africa, then crossing the Arabian Peninsula (March - April) and the rest of the Middle East (April - early-May) to the north-east on a rather broad front before converging towards south-eastern Kazakhstan (mid-April - May). Also in this case, the scarce units of white-headed yellow wagtail migrate together with their conspecifics of other subspecies.

The route between Asia and Africa is certainly used both by intermediate individuals leucocephala $\mathrm{x}$ bee$m a$ from the southern part of the Tuva Republic and from Achit Lake, and by first generation intraspecific hybrids lutea x beema from the Volga valley and, potentially, from Kazakhstan. Even the pale-headed birds observed in Greece are more likely to be lutea x beema hybrids. Hence, as also highlighted by Campbell and Moran (2016), in the Middle East, Eastern Mediterranean, and Africa much attention must be paid when observing western yellow wagtails with pale heads to discriminate true leucocephala from other apparently similar intermediate forms. In the Mediterranean basin, a similar problem could derive from the observation of specimens of channel wagtail (flava x flavissima), usually rather similar to beema, with a particularly pale head.

\section{Characteristics of males of different forms of western yellow wagtail with pale head}

Based on the examination of individuals observed and/or photographed in nature and specimens preserved in museums, we provide some items for distinguishing the true male of Motacilla flava leucocephala from apparently similar individuals.

\section{Motacilla flava leucocephala}

- White head with a variable ammount of very indistinct pale grey smudges on ear-coverts, sides of rear crown, and nape (Grant \& Mackworth-Praed, 1952; Cramp, 1988; Beaman \& Madge, 1998; Alström et al., 2003; van Duivendijk, 2010; Gombobaatar \& Leahy, 2019).
- Behind the orbit, possible presence of a very broad superciliary stripe feebly indicated (Sushkin, 1925c).

- Yellow throat with white upper throat, chin and malar more extensive than beema (Williamson, 1955; Alström et al., 2003; Gombobaatar \& Leahy, 2019).

- The lores and upper-most ear-coverts of the darkest birds are pale grey like the crown and ear-coverts (thus lacking the prominent loral stripe and eyestripe on the ear-coverts shown by beema) (Alström et al., 2003).

- A pale blue-grey band across the nape separates the white of the head from the mantle (Whistler, 1916; Williamson, 1955), with the colors between the head, back, and neck not clearly demarcated. Sometimes the nape is pale and yellowish forming an indistinct yellowish semicollar that "dilutes" into the back (Sushkin, 1925c).

- Back yellowish olive, more yellowish-tinged than in flava and beema, homogeneous in color, with no spots; rump of the same color of the back or yellowish citrine to pyrite yellow (Sushkin, 1925c).

- Borders of wing-coverts broad (about $5 \mathrm{~mm}$ ), whitish to primrose yellow, slightly wider than in flava and beema (Sushkin, 1925c; Alström et al., 2003).

- The large inner coverts have wide light margins which include the tip of the feathers, often with shaded coloration from white to yellowish cream.

- Under side lemon yellow to lemon chrome, with the exception of the white throat (Sushkin, 1925c).

- Most individuals show white tibia feathers (but this is also shown by some beema) (Alström et al., 2003).

In Figs. 10 and 11, skins of males with different amounts of gray on their head are presented.

\section{Intraspecific hybrid Motacilla flava leucocephala $x$ Motacilla flava beema}

- Light head with grayish shades; wider and noticeable whitish eyebrow behind the eye.

- The passage of color from the nape to the back is rather definite, less nuanced than leucocephala.

- Back with predominance of greyish-green shades, darker than leucocephala and usually with more or less marked speckles or mottling.

In Fig. 12, a presumed intraspecific hybrid Motacilla flava leucocephala x Motacilla flava beema.

\section{First generation intraspecific hybrid Motacilla flava lutea $x$ Motacilla flava beema}

- Light-head with forehead from pale ashen to whitish shade; hat, lores and ear-coverts from ashy gray to pure white (Sotnikov, 2006; Artemieva \& Muraviev, 2012a; 2012b; Redkin, 2013). Individuals with completely white heads are very similar to leucocephala, but the specimens with gray-shaded heads have gray-blackish lores. In leucocephala, the lores are white or pale grey like the crown and ear-coverts. 
- Back yellowish-gray or greenish-gray, darker than that of leucocephala, with more or less marked speckles or mottling. In leucocephala, the coloring is homogeneous.

- The rump is often lighter than the back, with more evident yellow-greenish shades compared to leucocephala.

- As in leucocephala, the larger outer coverts have wide clear margins which include the tip of the feathers, but proceeding inwards the margins gradually decrease until they disappear from the tip of the feathers in the area where they overlap the innermost scapular thus giving the impression of a pale bar that progressively narrows and disappears.

- Yellow tibia feathers, but they can also be white as leucocephala.

- Compared with leucocephala, it is a smaller bird size (Sotnikov, 2006).

In Fig. 13 and Fig. 14, presumed first-generation intraspecific hybrids Motacilla flava lutea x Motacilla flava beema.


Fig. 10 - Motacilla flava leucocephala. Specimen A) male, Phulbari (Lakhimpur District, Assam, India), 11 ${ }^{\text {th }}$ April 1950. (Courtesy University of Michigan, Museum of Zoology) / Esemplare A) maschio, Phulbari (distretto di Lakhimpur, Assam, India), 11 aprile 1950. (Per gentile concessione dell'Università del Michigan, Museo di Zoologia) (Photo / Foto: Rachel Wadleigh). Specimens B) male, Phulbari (Lakhimpur District, Assam, India), 12 ${ }^{\text {th }}$ April 1950. (Courtesy University of Michigan, Museum of Zoology). / Esemplare B) maschio, Phulbari (distretto di Lakhimpur, Assam, India), 12 aprile 1950. (Per gentile concessione dell'Università del Michigan, Museo di Zoologia). (Photo / Foto: Rachel Wadleigh). 


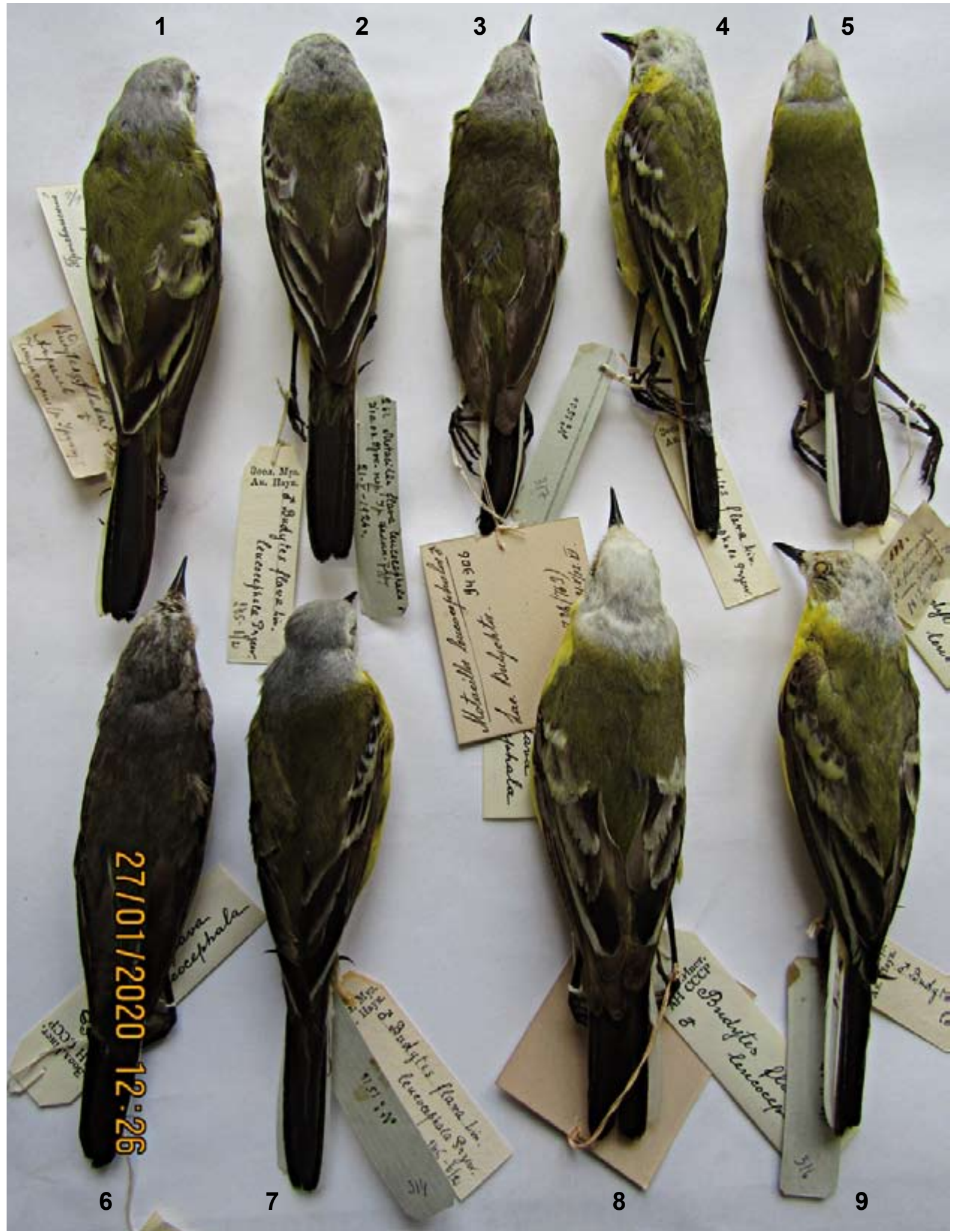

Fig. 11a - Motacilla flava with a pale head in the collection of the Zoological Institute of Russian Academy of Sciences (Saint Petersburg). / Motacilla flava con testa pallida nella collezione dell'Istituto Zoologico dell'Accademia russa delle scienze (San Pietroburgo). (Photo / Foto: Alexander Lvovsky). 1) M. f. Leucocephala, male/maschio, Urungu Lake, Dzungaria, China, 04/01/1879, Przhevalsky. 2) $M$. $f$. leucocephala, male/maschio, Orog Lake, Mongolia, 05/21/1926, Kozlova. 3) Presumed/Presunto M. f. lutea x M. f. beema, male/maschio, Bulukhta Lake, Volgograd Oblast, Russia, 06/12/1843. 4) M.f. leucocephala, male/maschio, Orog Lake, Mongolia, 05/19/1926, Kozlova. / 5) Presumed/Presunto M. f. lutea x M. f. beema, male/maschio, Žanaqala District (West Kazakhstan Region), 04/25/1862, Severtsev. 6) M. f. beema?, female/femmina, river Chagan, right-hand side of the river Ural/ fiume Chagan, lato destro del fiume Ural, 07/16/1862, Severtsev. 7) M. f. leucocephala, male/maschio, Orog Lake, Mongolia, 05/21/1926, Kozlova. 8) M. f. leucocephala, male/maschio, lower river Tsagal-norich-gol, Khara-gobi, 06/27/1914, Sushkin. 9) M. f. leucocephala, male/maschio, Orog Lake, Mongolia, 05/11/1926, Kozlova. 

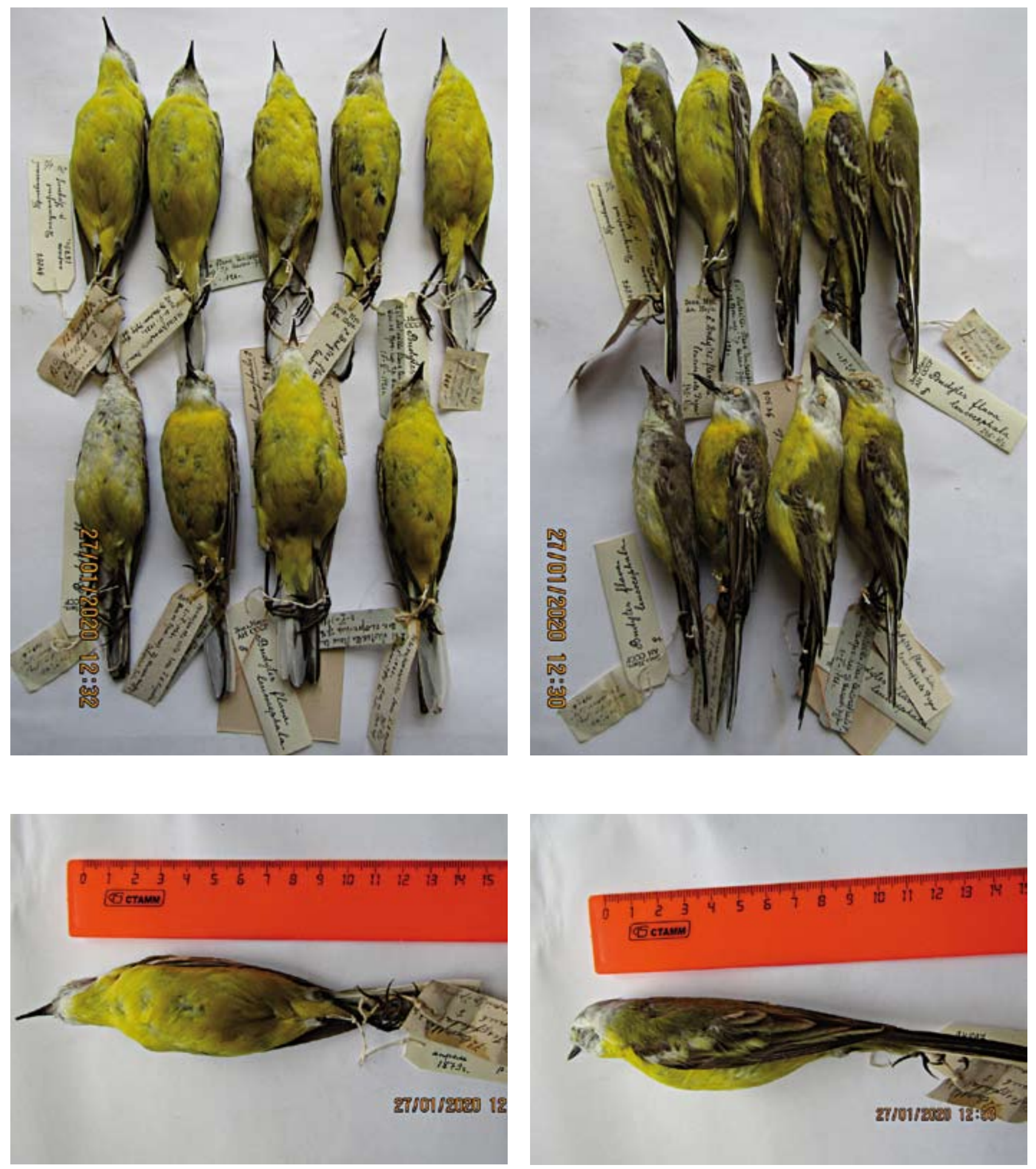

Fig. 11b - Motacilla flava with a pale head, in ventral and lateral view, in the collection of the Zoological Institute of Russian Academy of Sciences (Saint Petersburg). / Motacilla flava con testa pallida, in versione ventrale e laterale, della collezione dell'Istituto Zoologico dell'Accademia russa delle scienze (San Pietroburgo). (Photo / Foto: Alexander Lvovsky). Below detail of specimen no. 1. / Sotto dettaglio dell'esemplare n. 1. 


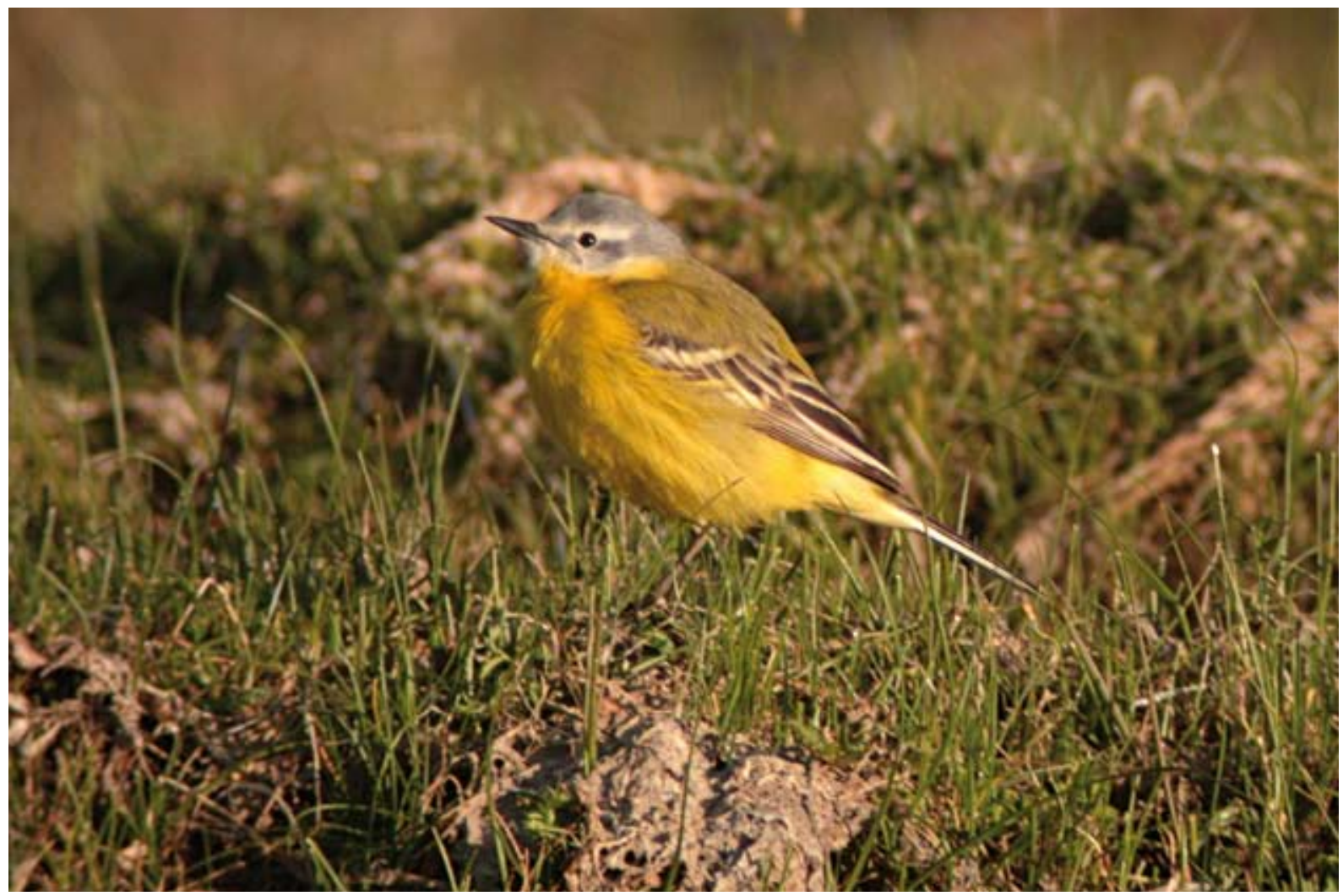

Fig. 12 - Presumed intraspecific hybrid Motacilla flava leucocephala x Motacilla flava beema, male, Achit Lake, Bayan-Ölgii and Uvs provinces, Mongolia, $15^{\text {th }}$ June 2017. / Presunto ibrido intraspecifico Motacilla flava leucocephala x Motacilla flava beema, maschio, Ačit Nuur, province di Bajan-Ôlgij e Uvs, Mongolia, 15 giugno 2017. (Photo / Foto: Magnus Hellström).

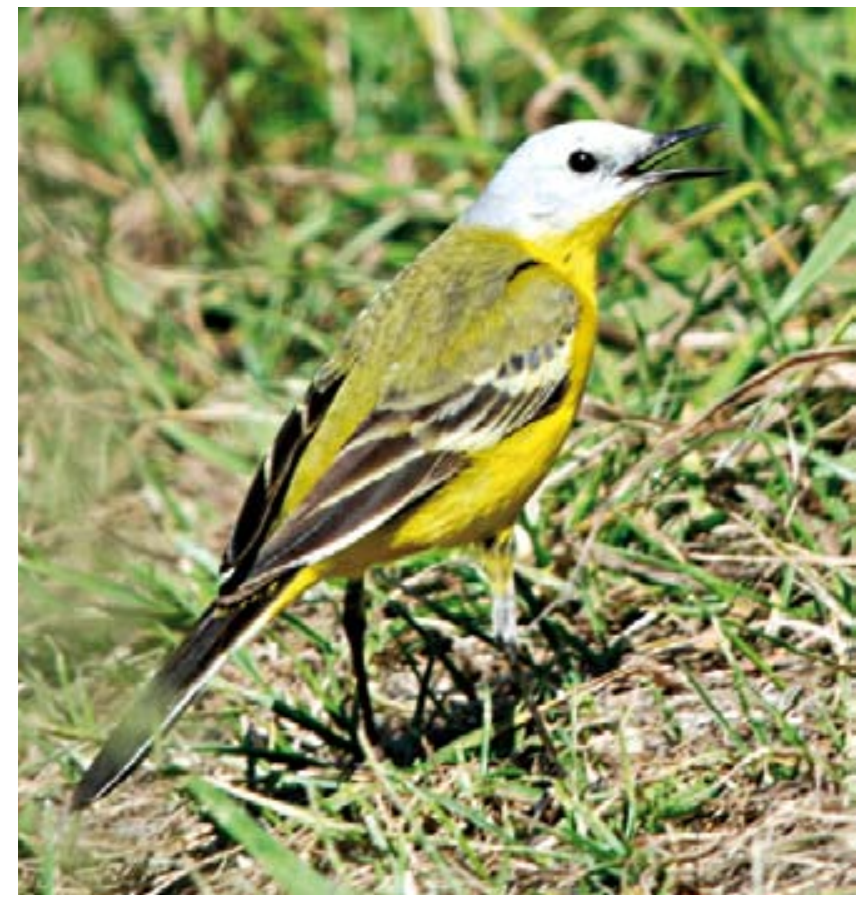

Fig. 13 - Presumed first-generation intraspecific hybrid Motacilla flava lutea x Motacilla flava beema, male, Dimitrovgrad, Melekessky District, Ulyanovsk Oblast, $1^{\text {st }}-2^{\text {nd }}$ May 2016. / Presunto ibrido intraspecifico di prima generazione Motacilla flava lutea x Motacilla flava beema, maschio, Dimitrovgrad, distretto di Melekesskij, Oblast' di Ul'janovsk, 1-2 maggio 2016. (Photo / Foto: Natalya Neverova).

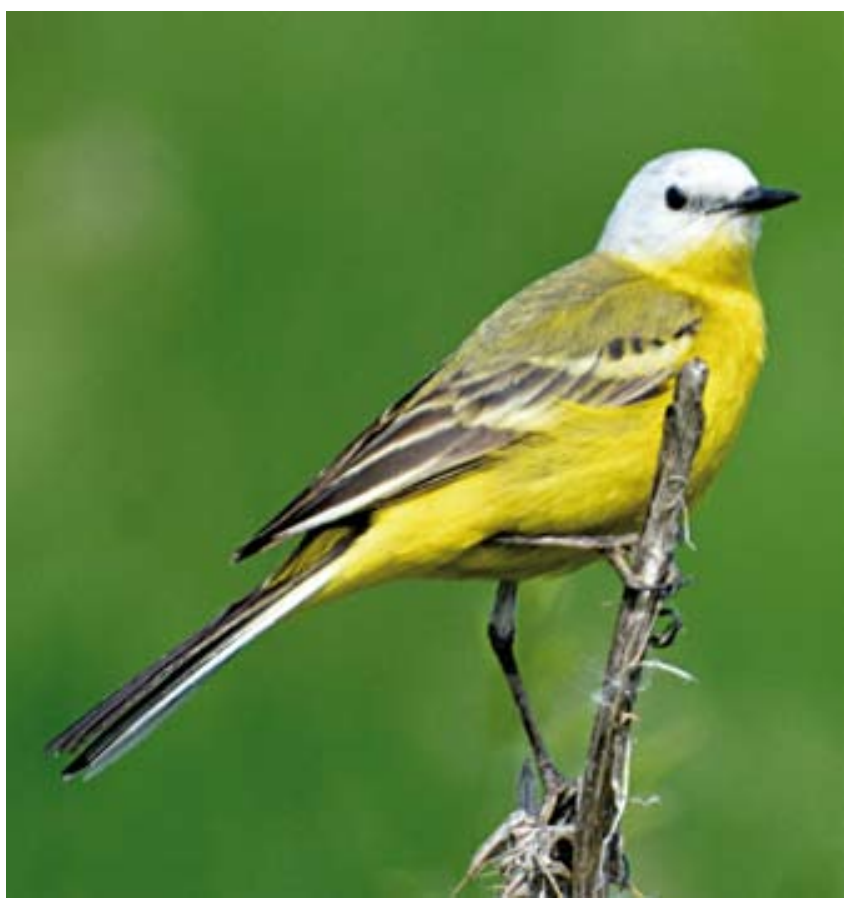

Fig. 14 - Presumed first-generation intraspecific hybrid Motacilla flava lutea x Motacilla flava beema, male, Kulikovka, Melekessky District, Ulyanovsk Oblast, 31 ${ }^{\text {st }}$ May 2016. / Presunto ibrido intraspecifico di prima generazione Motacilla flava lutea x Motacilla flava beema, maschio, Kulikovka, distretto di Melekesskij, Oblast' di Ul'janovsk, 31 maggio 2016. (Photo / Foto: Tatyana Kezhevatova). 


\section{Intraspecific hybrid Motacilla flava flava $x$ Motacilla flava flavissima (channel wagtail)}

- Light gray head, often with a paler forehead both on the vertex and on the nape, with white supercilium, usually distinguishable, broad and very flared behind the eye (Dubois, 2001; 2007; Baxter, 2010). Occasionally the head may be completely whitish (Dubois, 2001; 2007).

- Occasionally green-yellow feathers on the crown, supercilium and ear coverts (Dubois, 2001; 2007).

- Lores often very light or absent, but they can also be marked.

- White sub-ocular patch, distinctly extensive in size and solid white, which extends well towards the rear of the ear coverts (Baxter, 2010).

- Compared with leucocephala: passage of color from the nape to the back rather definite, darker olive-green plumage of the back, whitish margins of secondary coverts normally smaller, yellow plumage of the legs. In Fig. 15, a presumed intraspecific hybrid Motacilla flava flava x Motacilla flava flavissima.

\section{CONCLUSIONS}

The Motacilla flava leucocephala breeds from the third week of May along the banks of lakes; lakes are low and swampy at times, with a marked change in plant communities as they move away from the water. This means that the vegetation suitable for nesting and feeding the subspecies is normally located in a band less than a kilometer wide around the lakes. The overall surface suitable for reproduction is therefore very limited.

With respect to climate change, in the Mongolian part of the Altai-Sayan Ecoregion the increase in average annual temperature as much as $1.8-2.8{ }^{\circ} \mathrm{C}$ in just the first quarter of the $21^{\text {st }}$ century could result in the expansion of the Gobi Desert and melting the glaciers that feed the lakes of the Great Lakes Depression with, in the long term, a possible contraction of their size, as has already happened in other areas of the Mongolian Plateau (Kokorin et al., 2001; Tao et al., 2015). If this trend becomes real, the impact on the leucocephala habitat will be significant. Another possible reason for the alteration of the reproductive environment is given by



Fig. 15 - Presumed intraspecific hybrid Motacilla flava flava $\times$ Motacilla flava flavissima, male, Cley, Norfolk, England, $7^{\text {th }}$ May 2012. / Presunto ibrido intraspecifico Motacilla flava flava x Motacilla flava flavissima, maschio, Cley, Norfolk, Inghilterra, 7 maggio 2012. (Photo / Foto: Steve Gantlett / <sgbirdandwildlifephotos.co.uk>). 
excessive cattle grazing near the lakes, which possibly also destroys nests containing eggs and chicks (Gombobaatar et al., 2011) (Fig. 16).

In the past (late $19^{\text {th }}$-early $20^{\text {th }}$ century) the Motacilla flava leucocephala seemed not to be particularly rare. In fact Prjevalsky (1887), speaking of migration in the northern half of Xinjiang (China) on $15^{\text {th }}-27^{\text {th }}$ April 1879, stated: «They kept in small flocks, from five to ten individuals in each, and were frequently seen.», and Kozlova (1933) found it not uncommon in May 1926 at Orog Lake (Mongolia). Migrating flocks were observed also in Pakistan in 1939 and 1940 (Whistler, 1940; Waite, 1962). Still, in the mid-twentieth century as many as 18 specimens were captured in a few days (between $10^{\text {th }}$ and $27^{\text {th }}$ April 1950) in the same location in India (Lakhimpur District, Assam) (University of Michigan Museum of Zoology, 2019). Sushkin (1938) found this bird common during the breeding seasons of 1911 and 1914 at Achit Lake (Mongolia). From 2007 to 2017, instead, at the same lake a maximum of only 3 males were observed (Malmaeus, 2007; Faveyts, 2009; Rubythroat Birding Tours, 2013; Valkenburg, 2016; Hellström, 2017), and Oleg Belyalov (in Birds.kz, 2019), despite looking for it, did not find leucocephala in 2009. During the $21^{\text {st }}$ century, only dozens of birds have been reported near the lakes of both the Great Lakes Depression and southern Tuva (up to 75 at Khar-Us
Lake, John Allcock on eBird.org, 2019) and, despite the increase in the number of ornithologists and birdwatchers, in the course of migration very small groups are rarely reported (usually individuals appear). Making a serious quantitative comparison between historical records and the current counts is materially impossible, however the feeling transmitted by these data is that there has been a numerical decline in the subspecies.

Considering also the new situation of partial overlap of area with beema (whose overall population is certainly much larger), one can well understand and share the concern expressed by Russian ornithologists for the conservation of the habitat of the leucocephala (Ondar \& Shaulo, 2018) and for the danger that this subspecies could be "absorbed" by hybridization by beema (Ilyashenko, 2011).

\section{Acknowledgements}

We heartedly thank Fakhar Abbas (Bioresource Research Center, Islamabad, Pakistan), Raffele Gemmato (Stazione Ornitologica Modenese "Il Pettazzurro"), Madeeha Manzoor (Bioresource Research Center, Islamabad, Pakistan), Silas Olofson, Yoav Perlman (Israel Ornithological Center), Colin Richardson (Ornithological Society of the Middle East), Machiel Valkenburg (Rubythroat

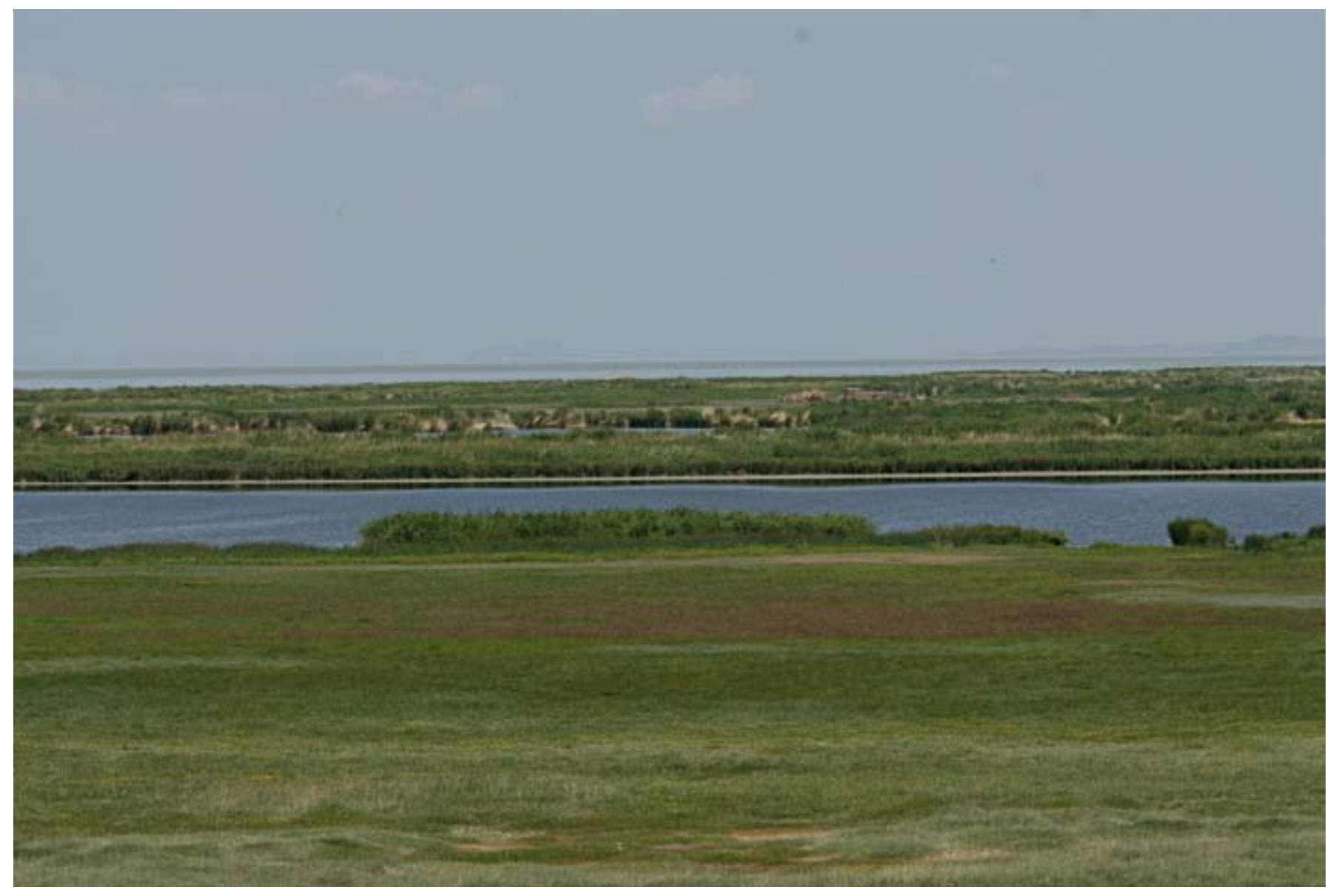

Fig. 16 - Western shore of Khar-Us Lake, Khovd province, Mongolia, 23 ${ }^{\text {rd }}$ July 2012. / Riva occidentale del lago Khar-Us, provincia di Hovd, Mongolia, 23 luglio 2012. (Photo / Foto: Gombobaatar Sundev). 
birding tours) and Jill Williams (Sunbird) for the information they have kindly supplied. The authors sincerely thank Alexander Lvovsky for the photographs of carcasses of wagtails from the collection fund of the Zoological Institute of the Russian Academy of Sciences (Saint Petersbourg, Russia), Brett W. Benz, Cody W. Thompson and Rachel Wadleigh for the photographs of carcasses of wagtails from the collection fund of the Museum of Zoology of the University of Michigan (Ann Arbor, USA), as well as Zachary Collier, Paul French (Sunbird, British Birds Rarities Committee), Steve Gantlett (SG Bird and Wildlife Photos), Dmitry Grudinin, Magnus Hellström (SOF BirdLife AviFauna Natureresort), Tatyana Kezhevatova, and Natalya Neverova for the other photographs. Special thanks to the Editor and to the anonymous referees for the critical revision of the text and for the valuable suggestions. We are also grateful to Kelsey Horvath for the revision of English text.

\section{REFERENCES}

AfricanBirdClub, 2010 - Recent Reports. Bulletin of the African Bird Club, 17 (1)

Ali S. \& Ripley S. D., 1987 - Compact handbook of the birds of India and Pakistan. Oxford University Press, Delhi.

Al-Sirhan A., 2009 - The Kuwait Bird Report 2008. Kuwait Ornithological Rarities Committee (KORC).

Al-Sirhan A., 2010 - Kuwait Annotated Checklist of Birds, KORC Secretary, 20 June 2010.

Al-Sirhan A., 2018 - KORC Annotated Checklist of Birds. KORC Secretary. $<$ https://birdsofkuwait.com/annotated_checklist.shtml $>$

Alström P., Mild K. \& Zetterström B., 2003 - Pipits \& Wagtails of Europe, Asia and North America. Identifications and Systematics. Christopher Helm, London.

Artemyeva E. A. \& Muravyev I. V., 2012a - The sympathy of the «yellow» wagtails (Passeriformes, Motacillidae, Motacillinae): geography, ecology, evolution. Part 1. Flint-Nauka, Moscow.

Artemyeva E. A. \& Muravyev I. V., 2012b - The sympathy of the «yellow» wagtails (Passeriformes, Motacillidae, Motacillinae): geography, ecology, evolution. Part 2. Flint-Nauka, Moscow.

Artemyeva E. A., Muravyev I. V. \& Kalinina D. A., 2013 - Желтолобая трясогузка в оопт «Озеро Песчаное» ульяновской области. In: Problems and outlook of bird conservation in Russia. Dzhamirzoyev G.S. (ed.). Proceedings of the All-Russian Conference, dedicated to the $20^{\text {th }}$ anniversary of Russian Bird Conservation Union (Moscow, 7-8 February 2013), Moscow - Makhachkala: 38-41.

Artemyeva E. A., Kalinina D. A. \& Makarov D. K., 2014 Гнездование желтолобой трясогузки (Passeriformes, Motacillidae) в ульяновской области. Биоразнообразие и устойчивость живых систем: материаль ХІІІ Международной научнопрактической экологической конференции (г. Белгород, 6-11 октября 2014 г.): 16-17.

Artemyeva E. A., Kalinina D. A. \& Makarov D. K., 2015a-Мониторинг гнездования желтолобой трясогузки (Passeriformes, Motacillidae) в среднем поволжье. Зоологические чтения, Материаль Международной научнопрактической конференции (Гродно, 22-24 апреля 2015 г.): 29-32.

Artemyeva E. A., Makarov D. K. \& Kalinina D. A., 2015b - Study of the avifauna of SPA «Sand Lake» as a stage of integration in IBA net of Ulyanovsk Region. Инвентаризация, мониторинг $и$ охрана ключевых орнитологических территорий России, 7: $17-18$.

Ash J. \& Atkins J., 2009 - Birds of Ethiopia and Eritrea. An Atlas of Distribution. Cristhopher Helm, London.

Ashby S., 2014 - Unusual wagtail subspecies found in 2014. <http:// www.kazakhstanbirdtours.com/news/wagtails-2014.html>

Ashby S.,Ashby V. \& Kenefik M., 2012-Birdwatching. Казахстанский орнитологический бюллетень 2007: 103-107.
Baker E. C. S., 1926 - The Fauna of British India including Ceylon and Burma. Birds Vol. 3 (Second Edition). Taylor \& Fancis, London.

Balmer D. \& Betton K., 2003 - Around the Region. Sandgrouse, 25 (2): $154-160$.

Balmer D. \& Betton K., 2005 - Around the Region. Sandgrouse, 27 (2): $170-176$.

Balmer D. \& Betton K., 2006 - Around the Region. Sandgrouse, 28 (2): 184-192.

Bâlon D. \& Burban A., 2008 - Voyage en Mongolie du 15 juillet au 13 août 2008. <https://www.lpo.fr/images/voyagesornithos/Mongolie/ Mongolie_2008_Balon.pdf $>$

Baranov A. A., 2007 - Пространственновременная динамика биоразнообразия птиц АлтайСаянского экорегиона и стратегия его сохранения. Диссертации на соискание ученой степени Доктора Биологичес, Ulan-Udè.

Baranov A. A., 2012 - Birds of the Altai-Sayan Ecoregion: spatio-temporal dynamics of biodiversity: monograph. Krasnoyarsk. state ped un-t them. V.P. Astafieva. Krasnoyarsk.

Baranov A. A., 2013 - Processes of bird formation in the territory of Middle Siberia. In: «New Humanity» of modern Europe: crisis of culture or progress of civilizations? Astafyeva V.P. (ed.). Вестник Красноярского государственного педагогического университета, 3 (25): 212-214.

Bauer W., Helversen O. V., Hodge M. \& Martens J., 1969 - Aves. In: Catalogus Faunae Greciae. Kanellis A. (ed.). Thessaloniki.

Baumgarten M., 2018 - Breeding bird survey in western Azerbaijan. $<$ http://birdingaze.blogspot.com/2018/05/>

Baxter P. A. A., 2010 - 'Channel' and Sykes's Wagtails in Scotland: a review of identification criteria and status. Scottish Birds, 30 (3): 266-272.

Bayarhuu S. \& Bräunlich A., 2007 - Support of HUN Club's conservation and public awareness activities in W Mongolia. Asian Waterbird Conservation Fund. <http://assets.wwf.org.hk/downloads/ wwfhk_asian_waterbird_conservation_fund_mongolia_final_report_june_2006.pdf>

Beaman M. \& Jännes H., 2008 - Serengeti \& Ngorongoro 6 - 20 March 2006. <http://www.birdquest-tours.com/pdfs/report/TANZANIA\%20(SERENGETI)\%202\%20REP\%2006.pdf> (Retrieved in December 2017).

Beaman M. \& Madge S., 1998 - The Handbook of Birds Identification for Europe and the Western Paleactic. Chistopher Helm, A \& B Black, London.

Belyalov O. V. \& Karpov F. F., 2012 - Птицы Сорбулакской системы озёр (Алматинская область). Selevinia, 20: 82-108.

Bennett K. J., 1997 - Evolution and Ecology: The Pace of Life. Cambridge University Press, Cambridge.

Benson C. W., 1951 - The bird-life of Lake Nyasa. The Nyasaland Journal, 4 (2): 49-66.

Bird S. \& Annenkova S., 2007-Kazakhstan-May 2007.<http://www.kazakhstanbirdtours.com/reports/kazakhstan-birdseekers-2007.pdf>

Birding Hong Kong, 2019 - Latest Sightings - March 2019 - March 1-10. <https://www.birdinghongkong.com/march-2019.html >

birds.kz, 2019 - North Mongolian Yellow Wagtail Motacilla flava leucocephala (Przevalski, 1887) Белоголовая желтая трясогузка Сары шақшақай. <http://birds.kz/v2taxon.php?s=396\&l=en>

Bolshakov C. V., 2001 - Results of a large-scale study of nocturnal avian migration in the arid and mountainous zone of western Central Asia (the "ASIA" programme) (in Russian). In: Actual problems of bird study and conservation in Eastern Europe and Northern Asia. Abstract XI International Ornithological Conference. Matbugat Jorty, Kazan: 7-8.

Bolshakov C. V., 2003 - Nocturnal Migration of Passerines in the Desert-Highland Zone of Western Central Asia. In: Avian Migration. Berthold P., Gwinner E. \& Sonnenschein E. (eds.). Springer, Berlin.

Borodavko P. S., 2009 - Pleistocene lake level changes in Western Mongolia. Geophysical Research Abstracts, 11, EGU General Assembly 2009. <https://meetingorganizer.copernicus.org/EGU2009/ EGU2009-1805.pdf>

Bostanzhoglo V. N., 1911 - Орнитологическая фауна АралоКаспийских степей. Материалы к познанию фауны и флоры Российской империи. Отд. зоологии. Bып. 11. 
Bräunlich A., 2007a - Field Trip to Ayrag Lake-Ramsar Site, western Mongolia 12/13 May 2007. Asian Waterbird Conservation Fund.

Bräunlich A., 2007b - Khovd, early-May 2007. <http://birdsmongolia. blogspot.com/2007/05/khovd-early-may-2007.html>

Brelsford C., 2017 - Northern Xinjiang, July 2017. <https://www. shanghaibirding.com/xinjiang-intro/>

British Ornithologists' Union Records Committee, 2007 - 35 th Report (April 2007). The Ibis, 149: 652-654.

Britton P. L. (ed.), 1980 - Birds of East Africa: their habitat, status and distribution. East Africa Natural History Society, Nairobi.

Buchheim A., 2013 - Gullivers's Travels 2012, part four (final): The Birding Days. $<$ http://birdsmongolia.blogspot.com/2013/02/gulliverss-travels-2012-text-by-andreas.html $>$

Campbell O. \& Moran N., 2016 - Phenology of spring landbird migration through Abu Dhabi island, United Arab Emirates, 2007-2014. Sandgrouse, 38: 38-70.

CASD (China Animal Scientific Database), $2019-<$ http://www. zoology.csdb.cn/page/showTreeMap.vpage?uri=cnfauna. tableTaxa\&id=A5557653-B033-4D12-A779-C6C0E8CCA761> (retrieved November 2019).

Central Asia Birding, 2009-Exploring Taukum Desert Kazakhstan 2009 - 09-05-2009 till 11-05-2009. <http://www.rubythroatbirdingtours. com/wp-content/uploads/2017/11/TAUKUM DESERT 2009. pdf $>$

Constantine W. B., 1971 - The Birds of Zambia. Collins.

Constantine W. B. \& Benson F. M., 1977 - The Birds of Malawii. Montfort Press.

Cramp S. (ed.), 1988 - Handbook of the Birds of Europe, the Middle East and North Africa. The birds of the Western Palearctic. Vol. 5. Tyrant Flycatchers to Thrushes. Oxford University Press, OxfordNew York.

Das A., 2011 - White-headed Yellow Wagtail - Boshipota, WB 27.02.11 <http://indianbirdsphotography.blogspot.com/2011/02/ birdphotoindia-white-headed-yellow.html>

Dawaa N., Busching W-D., Sumijaa D., Bold A. \& Samijaa R., 1994 - Kommentierte Checkliste der Voegel and Saeuger der Mongolei. Naumann-Museum, Koethen.

Deka J., Raj M., Saikia P. K. \& Bhattacharjee P. C., 1996 - A contribution to the avifauna of Darrang District, Assam, India. Tiger Paper, 23 (1): 17-21.

Dementiev G. P. \& Gladkov N. A. (eds.), 1954 - Ptitsy Sovyet Soyuza. [The birds of the Soviet Union]. Vol. 5. Sovetskaya Nauka, Moskva.

Department of Wildlife Protection, Govt. of Jammu and Kashmir, 2011 - An overview 2001-2010. <http://www.jkwildlife.com/pdf/pub/ book $\% 20$ wildlife.pdf $>$

Dev, 2018 - Xinjiang - A painful birding trip full of administrative shenanigans. <http://gamebirds.me/2018/08/28/xinjiang-administrative-shenanigans/>

Dolnik V. R., 1990 - Bird migration across arid and mountainous regions of middle Asia and Kasakhstan. In: Bird Migration: Physiology and Ecophysiology. Gwinner E. (ed.). Springer-Verlag, Berlin.

Dubois P. J., 2001 - Les formes nicheuses de Bergeronnette printanière Motacilla flava en France. Ornithos, 8 (2): 44-73.

Dubois P. J., 2007 - Yellow, Blue-headed, 'Channel' and extra-limital wagtails: from myth to reality. Birding World, 20 (3): 104-112.

Dubois P. J., 2016 - Mongolie. Le désert de Gobi. <https://www.escursia.fr/sites/public-files/escursia.fr/cr-mongolie_2016_pdf $>$

Dufourny H., 2010 - Voyage Ornithologique en Mongolie du 25 mai au 11 juin $2010 .<$ https://studylibfr.com/doc/3966951/mongolie>

eBird.org, $2019-<$ https://ebird.org/>

Ennoil0202, 2014 - Mongolia 13 Uvs aimak Birds at Bayannuur. $<$ https://www.youtube.com/watch? $\mathrm{v}=$ DgXH3HEEqf8>

Eriksen J., 2017 - Oman Bird List, edition 7.7 (JE, 6 Mar 2017).

Eriksen J. \& Porter R., 2017 - Birds of Oman. Christopher Helm, London.

Erokhov S. N. \& Berezovikov N. N., 2009-Материалы к орнитофауне озёрной степи и лесостепи кустанайской области, Часть 2. Русский орнитологический журнал, 18 (517): 1751-1780.

Fågel P., 2008 - 28/04/2008 at JEO. <https://www.birdsofkuwait.com/ blog/2008/04/28/28042008-at-jeo/>
Faucett R., 2016 - UWBM Ornithology Collection. University of Washington Burke Museum. Occurrence dataset $<$ https://doi. org/10.15468/a2cmfl $>$ (accessed via GBIF.org on 2019-1029).

Faveyts W., 2009 - Trip Report - Southern Siberia / Western Mongolia Birding in the heart of Asia June $4^{\text {th }}-$ June $27^{\text {th }} 2009$. $<\mathrm{http}: / /$ www.mos.mn/eng/images/reports/SOUTHERN\%20SIBERIA \%20 and\%20WESTERN\%20MONGOLIA 2009.pdf $>$

Finlayson C., 2011 - Avian survivors: The History and Biogeography of Palearctic Birds. $T \& A D$ Poyser, London.

Ferlini F., 2015 - Evoluzione dell'areale riproduttivo della Cutrettola "italiana" Motacilla flava cinereocapilla. Rivista Italiana di Ornitologia, 85 (2): 3-18.

Ferlini F., 2016 - Evolution of the breeding range of the Black-headed Yellow Wagtail (Motacilla flava feldegg). Rivista Italiana di Ornitologia, 86 (1): 3-38.

Ferlini F., 2020 - Wintering range of Western Yellow Wagtail Motacilla flava in Africa and Europe in a historical perspective. Rivista Italiana di Ornitologia, 90 (1): 3-39.

Ferlini F. \& Artemyeva E. A., 2020 - The Gmelin's wagtail Parus luteus: breeding range, migratory movements and wintering range. Rivista Italiana di Ornitologia, 90 (2): 3-50.

Flickr.com, 2019 - Motacilla flava leucocephala. <https://www.flickr. $\mathrm{com} />$

Fomin V. E. \& Bold A., 1991 - Каталог птиц Монгольской Народной Республики. Наука, Москва.

Ganguli U., 1975 - A field guide to the birds of the Delhi area. Indian Council of Agricultural Research, New Delhi.

Gavrilov E. I. \& Gavrilov A. E., 2005 - The birds of Kazakhstan. Abridged version. Tethys Ornithological Research, 2: 3-222.

Gedeon K., Zewdie C. \& Töpfer T., 2017 - The birds (Aves) of Oromia, Ethiopia - an annotated checklist. European Journal of Taxonomy, 306: 1-69.

Giannella C. \& Tinarelli R., 2003 - Resoconto Ornitologico dell'EmiliaRomagna. 2002. Picus, 55: 9-18.

Gombobaatar S. \& Leahy C., 2019 - Birds of Mongolia. Princeton University Press, Princeton \& Oxford.

Gombobaatar S. \& Monks E. M. (compilers), Seidler R., Sumiya D., Tseveenmyadag N., Bayarkhuu S., Baillie J. E. M., Boldbaatar Sh. \& Uuganbayar Ch. (eds.), 2011 - Regional Red List Series Vol.7. Birds. Zoological Society of London, National University of Mongolia and Mongolian Ornithological Society.

Government of Khyber Pakhtunkhwa, 2013 - Upgradation / rehabilitation of road from Shamozai to Dadahara on the right bank of River Swat under Khyber Pakhtunkhwa emergency road recovery project (kp-errp) - environmental impact assessment. <http:// documents.worldbank.org/curated/en/655851468286263107/pdf/ E43870P147713000Box382090B00PUBLIC0.pdf $>$

Grant C. H. B. \& Mackworth-Praed C. W., 1952 - On the species and races of the Yellow Wagtails from Western Europe to Western North America. Bulletin of the British Museum (Natural History) Zoology, 1 (9): 253-270.

Gray D. A., 2014 - Your questions answered. Birdwatch, 266: 84.

Grimmett R. \& Inskipp T., 2003 - Birds of Northern India. Christopher Helm, London.

Grimmett R., Roberts T. J., Inskipp T. \& Byers C., 2008 - Birds of Pakistan. Christopher Helm, London.

Grimmett R., Inskipp C., Inskipp T., Baral H. S., 2016 - Birds of Nepal. Christopher Helm, London.

Grum-Grzhimaylo G. Е., 1914 - Западная Монголія и Урянхайскій Край. Томъ Первый. с.-Петербургь.

Handrinos G. \& Akriotis T., 1997 - The Birds of Greece. Christopher Helm, London.

Harrison I. \& Grieve A., 2012a - Around the Region. Sandgrouse, 34 (1): 93-110.

Harrison I. \& Grieve A., 2012b - Around the Region. Sandgrouse, 34 (2): $189-203$

Harvard University M. \& Morris P. J., 2019 - Museum of Comparative Zoology, Harvard University. Version 162.176. Museum of Comparative Zoology, Harvard University. Occurrence dataset $<$ https:// doi.org/10.15468/p5rupv> (accessed via GBIF.org on 2019-1029). 
Heiss M. \& Eidam F., 2015 - First record of White-headed Yellow Wagtail Motacilla flava leucocephala for Azerbaijan. Sandgrouse, 37 (2): 199-202.

Hellström M., 2017 - Altaj \& NV Mongoliet 6 - 21 juni 2017. <http:// avifauna.se/wp-content/uploads/sites/34/2018/10/Altaj-NV-Mongoliet-juni-2017.pdf>

Hendriks H., 2007 - A report on birds seen on a birding trip to Kazakstan from 5-20 May 2007. <https://www.rubythroatbirdingtours. com/wp-content/uploads/2017/11/Kazakstan-_2007_HenkHendriks.pdf>

Henry G. M., 1998 - A Guide to the Birds of Sri Lanka. Oxford University Press.

Hewitt G. M., 2000 - The genetic legacy of the Quaternary ice ages. Nature, 405: 907-913.

Hewitt G. M., 2004 - Genetic consequences of climatic oscillations in the Quaternary. Philosophical Transactions of the Royal Society B: Biological Sciences, 359: 183-195.

Holm S. R. \& Svenning J.-C., 2014 - 180,000 years of climate change in Europe: avifaunal responses and vegetation implications. PLoS ONE 9, e94021.

Holmen P., 2015 - Yellow Wagtail Motacilla flava. <http://www.persbirding-pages.com/www.pers-birding-pages.com/Yellow_Wagtail. html> (retrieved in December 2019).

Huang Ya-dong, Zhang Xian-feng \& Hu Hong-xing, 2009 - Primary Survey on Summer Birds in Yili River Wetland and its Vicinity. Sichuan Journal of Zoology, 28 (1): 133-139.

IBC, 2019 - The Internet IBC Bird Collection. < https://www.hbw.com/ $\mathrm{ibc} />$

Ikenaga H. \& Yanagisawa S., 2015 - The first record of Sykes's Yellow Wagtail, Motacilla flava beema from Japan. Japanese Journal of Ornithology, 64: 271-274.

Ikenaga H., Kawakami K. \& Yanagisawa N., 2014 - Records of species and subspecies newly published in the $7^{\text {th }}$ edition of the Japanese Birds Catalog Revision. Journal of the Japanese Society of Ornithology, 63 (1): 96-149.

Ilyashenko V. Yu., 2011 - Принципы составления Каталога редких птиц и Красной книги Российской Федерации. Орнитология, 36: $157-187$

iNaturalist.org, 2019 - iNaturalist Research-grade Observations. Occurrence dataset. $<$ https://doi.org/10.15468/ab3s5x $>$ (accessed via GBIF.org on 2019-10-29).

Inskipp C., Baral H. S., Phuyal S., Bhatt T. R., Khatiwada M., Inskipp T., Khatiwada A., Gurung S., Singh P. B., Murray L., Poudyal L. \& Amin R., 2016 - The status of Nepal's Birds: The national red list series. Zoological Society of London, UK.

Iran Bird Records Committee, 2019 - Records of population of important species in Iran. $<\mathrm{http}$ ://iranbirdrecords.ir/category/Subspecis/>

Irwin D. E. \& Irwin J. H., 2005 - Siberian Migratory Divides. The Role of Seasonal Migration in Speciation. In: Birds of Two Worlds: The Ecology and Evolution of Migration. Greenberg R. \& Marra P. P. (eds.). The Johns Hopkins University Press, Baltimore \& London.

Jackson P., 1965 - White-headed Yellow Wagtail near Delhi. Journal Bombay Natural History Society, 61 (2): 304-305.

Jayadevan P., Subramanya S. \& Raj V. M., 2018 - Karnataka checklist: Corrections and additions. Indian Birds, 14 (4): 127-128.

Karamzin A. I., 2003 - Птицы, наблюдавшиеся в окрестностях хутора Кум-Сая, Актюбинского уезда Тургайской области. Русский орнитологический журнал, Экспресс-выпуск, 215: 277-282.

Kehoe C. \& Khayankhayrvaa T., 2014 - Mongolia 24 May - 7/11 June 2014. <https://www.birdquest-tours.com/wp-content/ uploads/2019/06/MONGOLIA-REP-14-ebook.pdf>

Keith S., Urban E. K. \& Fry H. (eds.), 1992 - The Birds of Africa, Volume IV. Broadbills to Chats. Academic Press, London, UK.

Kennerley P. \& Kovshar V., 2007 - Kazakhstan: mountains, desert \& steppe May $6^{\text {th }}$ - May $19^{\text {th }} 2007$. Limosa Holidays \& The Travelling Naturalist. <https://www.limosaholidays.co.uk/reportpdfs/KAZAKHSTAN\%205-07\%20PK\%20tour\%20report.pdf>

Khaleghizadeh A., Roselaar K., Scott D. A., Tohidifar M., Mlíkovský J., Blair M. \& Kvartalnov P., 2017 - Birds of Iran: Annotated Checklist of the Species and Subspecies. Iranian Research Institute of Plant Protection. <http://www.agrilib.ir/book_4021.pdf>
Kilburn M., 1998 - Xinjiang Autonomous Region, China Birding 7-27 June 1998. <http://www.worldtwitch.com/xinjiang_kilburn.htm>

Kirwan G. M., Ozen M., Ertuhan M. \& Atahan A. (eds.), 2014 - Turkey Bird Report 2007-2011. Sandgrouse, 36 (2): 146-175.

Klunderud P., 2013 - Iran 11. - 28. april 2013 Natur og kulturreise. $<$ https://www.osme.org/sites/default/files/pdf/KNoK_Rapport_Iran_ april_2013.pdf>

Koblik E. A., Redkin Ya. A. \& Arkhipov V. Yu., 2006 - Checklist of the Birds of Russian Federation. KMK Scientific Press Ltd., Moscow.

Kokorin A. O., Kozharinov A. V. \& Minin A. A., 2001 - Ecoregional Climate Change and Biodiversity Decline, Issue 1, Altai-Sayan Ecoregion. WWF Climate Program. WWF Russia, Moscow.

Kolbintsev V. G., 2001 - Список птиц северного макросклона западной части Таласского Алатау. <http://www.shumkar.ru/ watching/kaz/aksu_jab.php>

Korepov M. V. \& Korepova D. A., 2013 - Square 39UUA3 Ulyanovsk region. In: The Fauna and Abundance of European Russia Birds. Annual report on the Programme «Birds of Moscow City and the Moscow Region», vol. 1. Voltzit O. V., Kalyakin M. V. (Eds.). «FitonXXI» Publ., Moscow: 599-603.

Korepov M. V., Korepova D. A., Stryukov S. A. \& Sitnikova V. A., 2014 - Square 39UUV3 Samara and Ulyanovsk Regions. In: The Fauna and Abundance of European Russia Birds. Annual report on the Programme «Birds of Moscow City and the Moscow Region", vol. 2. Voltzit O. V. \& Kalyakin M. V. (eds.). «FitonXXI»Publ., Moscow: 299-304.

Kozlova E. V., 1933 - The Birds of South-West Transbaikalia, Northern Mongolia, and Central Gobi. Part IV. The Ibis, 75 (1): 59-87.

KovsharV.A.,2012-Birdwatching.Казахстанскийорнитологический бюллетень 2007: 116-118.

Kovshar A. F. \& Berezovikov N. N., 2018 - Материалы по фенологии весенней миграции птиц в долине реки Копа (Юго-Восточный Казахстан). Русский орнитологический журнал, 27, Экспрессвыпуск 1666: 4467-4479.

Lebedeva G. P., 2017 - Square 39UVV1 Samara and Ulyanovsk regions. In: The Fauna and Abundance of European Russia Birds. Annual report on the Programme «Birds of Moscow City and the Moscow Region», vol. 8. Voltzit O. V. \& Kalyakin M. V. (eds.). KMK Scientific Press, Moscow: 484-490.

$\mathrm{Liu} \mathrm{Xu}, 2018$ - 新疆阿尔泰山鸟类多样性研究 $[\mathrm{D}]$. 新疆乌鲁木齐. 中国科学院大学.

Malmaeus M., 2007 - A report from a bird watching trip in S Russia and NW Mongolia May 24 - June 10 2007. <http://www.mos.mn/ eng/images/reports/Mikael_Malmaeus_2007.pdf $>$

Manzoor M., Shamim S. \& Khan F. M., 2017 - A Check list of the Avifauna of Loi-Bher Wildlife Park Islamabad. Journal of Bioresource Management, 4 (2): 32-44.

Martin T. E., Dubos J., Rivière T., Loubon M., Fleureau J., Martineau A., Guillemin M. \& Nivet-Mazerolles V., 2018 - Bird records from arid and semi-arid areas in southern Kazakhstan, 2009-2017. Sandgrouse, 40: 53-74.

Mayr E. \& Greenway J. C., 1960 - Check-list of birds of the world. Vol. 9. Museum of Comparative Zoology, Cambridge, Massachusetts.

Mirza Z. B., 1998 - Illustrated Handbook of Biodiversity of Pakistan. Oxford University Press.

Moskvichev A. N., 2013a - О некоторых интересных орнитологических находках в Ульяновске в 2013 г. Природа Симбирского Поволжья, 14: 120-131.

Moskvichev A. N., 2013b - Square 39UUA1 Ulyanovsk region. In: The Fauna and Abundance of European Russia Birds. Annual report on the Programme «Birds of Moscow City and the Moscow Region", vol. 1. Voltzit O. V., Kalyakin M. V. (eds.). «FitonXXI» Publ., Moscow: 588-590.

Moskvichev A. N., 2013c - Square 39UUA2 Ulyanovsk region. In: The Fauna and Abundance of European Russia Birds. Annual report on the Programme «Birds of Moscow City and the Moscow Region», vol. 1. Voltzit O. V., Kalyakin M. V. (eds.). «FitonXXI» Publ., Moscow: 591-595.

Moskvichyev A. N., 2013d - Square 39UUA4 Ulyanovsk Region. In: The Fauna and Abundance of European Russia Birds. Annual report on the Programme «Birds of Moscow City and the Moscow 
Region», vol. 1. Voltzit O. V., Kalyakin M. V. (eds.). «FitonXXI» Publ., Moscow: 606-610.

Moskvichev A. N., Borodin O. V., Korepov M. V. \& Korolkov М. А., 2011 - Птицы города Ульяновска: видовой состав, распространение, лимитирующие факторы и меры охраны. Издательство «Корпорачия технологий продвижения», Ульяновск.

Muravyev I. V., 2013 - Биоэкологические основы и механизмы симпатрии у птиц на примере видов группы «желтых» трясогузок (Passeriformes: Motacillidae, Motacillinae). Thesis, Ulyanovsk.

Muravyev I. V. \& Artemyeva E. A., 2012 - Yellow-headed Wagtail (Motacilla lutea) in the Volga-Kama and Volga Areas. Berkut, 21 (1-2): 102-115.

Muravyev I. V. \& Artemyeva Е. А., 2016 - К нидологии и оологии видов группы «желтых» трясогузок в поволжье. In: Современные концепции экологии биосистем и их роль в решении проблем сохранения природы и природопользования. Leonova N. A. (ed.): 139-142.

Murtaza A. \& Ahmed Khan A., 2010 - An avian systematic review and status of Motacillidae in Pakistan. Proceedings of Pakistan Congress of Zoology, 30: 230-231.

National Statistical Office of Mongolia, 2008 - Mongolian Statistical Yearbook 2008. National Statistical Office of Mongolia, Ulaanbaatar.

Newton I., 2008 - The Migration Ecology of Birds. Oxford Academic Press, Oxford.

Nikiforova V. V., 2015 - Square 38UPG2 Republic Chuvashiya. In: The Fauna and Abundance of European Russia Birds. Annual report on the Programme «Birds of Moscow City and the Moscow Region», vol. 5. Voltzit O. V. \& Kalyakin M. V. (eds.). KMK Scientific Press, Moscow: 344-347.

Nikolaus G., 1983 - Distribution Atlas of Sudan's Birds with notes on habitat and status. Zoologisches Forschungsmuseum Alexander Koenig, Bonner Zoologische Monographien, Bonn, 25.

Observation.org, 2018 - Motacilla flava leucocephala. $<$ https://observation.org/>

Oláh J., Khayankhayrvaa T. \& Munkhnast D., 2018 - Mongolia 19 May - 6 June 2018. BirdQuest. <https://www.birdquest-tours.com/wpcontent/uploads/2019/06/MONGOLIA-REP-18.pdf>

Ondar S. O. \& Shaulo D. N. (eds.), 2018 - Красная книга Республики Тыва (животные, растения и грибы). 2-е изд., перераб. Куzуl.

orientalbirdimages.org, 2019 - Western Yellow Wagtail. <www.orientalbirdimages.org/>

ovingthetodiesforever.blogspot.com, 2019 - Tai Sang Wai 28 Mar 2019 - yellow wagtail species. $<$ https://lovingthetodiesforever.blogspot. com/2019/03/tai-sang-wai-28-mar-2019-yellow-wagtail.html>

Pearson D. J., 1972 - The wintering and migration of palaearctic passerines at Kampala, Southern Uganda. The Ibis, 114 (1): 43-60.

Pearson D. J. \& Turner D. A., 1986 - The less common Palearctic Migrant Birds of Uganda. Scopus, 10 (3/4): 61-82.

Pedersen T. \& Aspinal S., 2010 - Checklist of the birds of the United Arab Emirates. Sandgrouse, Supplement 3.

Pleske T., 1889 - Wissenschaftliche Resultate der von N. M. Przewalski nach Central-Asien unternommenen reisen. Zoologischer Theil. Band II. Vogel. Lieferung I. Kaiserlichen Akademie der Wissenschaften, St. Petersburg.

PMDNDMA (Pakistan Meteorological Department National Disaster Management Authority), 2019 - Annexure 7 Birds of Pakistan. In: Environmental and Social Management Framework (ESMF) Draft. Pakistan Hydro-Meteorological and DRM Services Project.

Pope M. \& Zogaris S., 2012 - Birds of Kuwait. A Comprehensive Visual Guide. KUFPEC, BiodiversityEast.

Porter R. \& Aspinall S., 2010 - Birds of the Middle East. Christopher Helm, London.

Przewalski N. M., 1887a - Новые виды птиц Центральной Азии. Записки имп. Академии наук. Спб., 55: 76-95.

Przewalski N. M., 1887b - On New Species of Central-Asian Birds. The Ibis, 5 ( $5^{\text {th }}$ Series $): 401-417$.

Raghvendra V., Rahul V., Bharat C. \& Shivanand H., 2014 - Ornithofauna of Solapur (Ms), India. Indian Streams Research Journal, 4 (5): $1-10$
Raines R. J., 1962 - The distribution of birds in Northeast Greece in summer. The Ibis, 104 (4): 490-502.

Ramsay R. G. W., 1923 - Guide to the birds of Europe and North Africa. Gurney and Jackson, London/Edinburgh.

Rasmussen P. \& Anderton J. C., 2012 - Birds of South Asia: The Ripley Guide, $2^{\text {nd }}$ edition. Lynx Edicions, Barcelona, Spain, Smithsonian Institution, Washington, USA.

Redkin Ya. A., 2001 - Окраска оперения некоторых форм группы жёлтых трясогузок Motacilla flava sensu lato в ювенильном наряде. Русский орнитологический журнал, Экспресс-выпуск, 128: 3-27

Redkin Ya. A., 2011 - Новые данные о пространственных и репродуктивных отношениях некоторых близкородственных форм воробьинообразных Passeriformes в Туве. Русский орнитологический журнал 2011, 20, Экспресс-выпуск, 652: 839-853.

Redkin Ya. A., 2013 - Желтолобая трясогузка. In: Полный определитель птиц европейской части России. Kalyakina M.V. (ed.). 3: 60-63.

Reshetkova N. P., 2013 - К изучению орнитофауны Горнощитского Рыбопитомника (г. Екатеринбург). Regional Avifaunistic Journal, 18: 73-93.

Reynolds J. F., 1974 - Palearctic birds in East Africa. British Birds, 67: 70-76.

Richardson C. \& Porter R., 2020 - Birds of Cyprus. Helm Field Guides, London.

Roberts T. J., 1992 - The birds of Pakistan. Vol. 2. Oxford University Press, Karach.

Rockjumper, 2016 - Mongolia Birding the Gobi \& Beyond 22 ${ }^{\text {nd }}$ May to $10^{\text {th }}$ June 2016. Rockjumper. <https://www.rockjumperbirding. com/wp-content/uploads/Itinerary-RBT-Mongolia-2016.pdf>

Rubythroat Birding Tours, 2013 - Trip report Southwest Siberia \& Mongolia; Birding Altai June 16 - July 1, $2013<\mathrm{http} / /$ www.rubythroatbirdingtours.com/wp-content/uploads/2017/11/ ALTAI 2013.pdf $>$

Sevastyanov D. V., Shuvalov V. F. \& Neustrueva I. Yu. (eds.), 1994 Limnologiya i paleolimnologiya Mongolii (Limnology and Palaeolimnology of Mongolia). Nauka, St. Petersburg.

Shanghai Birding, 2019 - Mysterious Yellow Wagtail at Cape Nanhui, Shanghai. <https://www.shanghaibirding.com/wagtail-shanghai/>

Sharma S. C., 2005 - White-headed Yellow Wagtail Motacilla flava leucocephala (Przevalski) near Delhi, India. Indian Birds, 1 (3): 70-71.

Shirihai H., 1996 - The Birds of Israel. Academic Press, London

Shirihai H. \& Svensson L., 2018 - Handbook of Western Palearctic Birds, Volume 1: Passerines: Larks to Warblers. Helm.

Shnayder L. P., 2013 - Species list from a bird watching trip in Russian Altai and NW Mongolia June 16 - July 1 2013. <https:// www.rubythroatbirdingtours.com/wp-content/uploads/2017/11/ ALTAI 2013.pdf $>$

Shrestha T. K., 2001 - Birds of Nepal: Field Ecology, Natural History and Conservation Vol. 2. Bimala Shrestha, Kathmandu, Nepal.

Sneath D., 1998 - Ecology - State policy and pasture degradation in inner Asia. Science, 281 (5380): 1147-1148.

Sotnikov V. N., 2006 - Птицы Кировской области и сопредельных территорий - Т. 2 (1)., Триада С., Киров, 448 рр.

Stenzel T., Stubbe M., Samjaa R., Stubbe A. \& Dulamsuren C., 2005 Das Arteninventar der Avifauna der Mongolei wahrend einer NordSud-Durchquerung 1997. Erforschung biologischer Ressourcen der Mongolei (Halle/Saale), 9: 311-391.

Stepanyan L. S., 1990 - Конспект орнитологической фауны CCCP. Российская академия наук, Москва.

Stylianou J., 2016 - Systematic list for April 2016. BirdLife Cyprus The Monthly Checklist and society news, 5: 21-47.

Sushkin P. P., 1914 - Die Vögel der Mittleren Kirgisensteppe. Journal für Ornithologie, 62: 297-383.

Sushkin P. P., 1938 - Birds of the Soviet Altai and adjacent parts of north-western Mongolia. Vol. 2. Academy of Science of USSR Press, Moscow, Russia.

Sushkin P. R., 1925a - Exhibition of eggs collected by himself in the Altai and N.W. Mongolia. Bulletin of the British Ornithologists' Club, 45: 39. 
Sushkin P. R., 1925b - Exhibition of specimens of Budytesjlava leueocephala and Leucosticte marguritacea. Bulletin of the British Ornithologists' Club, 45: 40.

Sushkin P. R., 1925c - Notes on systematics and distribution of certain Palaearctic Birds. Proceedings of the Boston Society of Natural History, 38 (1): 1-55.

Tao S, Fang J., Zhao X., Zhao S., Shen H., Hu H., Tang Z., Wang Z. \& Guo Q., 2015 - Rapid loss of lakes on the Mongolian Plateau. Proceedings of the National Academy of Sciences, 112 (7): 22812286.

Tarasov P. E., Harrison S. P., Saarse L., Pushenko M. Y., Andreev A. A., Aleshinskaya Z. V., Davydova N. N., Dorofeyuk N. I., Efremov Y. V., Yu V., Khomutova V. I., Sevastyanov D. V., Tamosaitis J., Uspenskaya O. N., Yakushko O. F. \& Tarasova I. V., 1994 - Lake status records from the Former Soviet Union and Mongolia: Data Base Documentation. NOAA Paleoclimatology Publications Series. 2. Report. Springer Verlag.

Tarsiger.com, 2019 - Gallery. <http://www.tarsiger.com/>

Ticehurst C. B., 1915 - Exhibition and remarks upon a very rare Wagtail, Motacilla flava leucocephala (Przew.). Bulletin of the British Ornithologists' Club, 35: 59-60.

Tokorozaki S., 2011 - A subspecies of the Tokara archipelago, Kagoshima Prefecture. Birder, 25 (9): 48-50.

Townshend T., 2013 - Latest bird news from Beijing. <http://birdingbeijing.com/latest-bird-news-from-beijing/> (retrieved on December 2015).

Tserensodnom Z., 1971 - Mongol orny Nuur. TUAH, Ulaanbaatar.

Tsvetkov A. V., Redkin Ya. A. \& Koblik E., 2003 - О распространении и биологии трясогузок в Туве. Русский орнитологический журнал 2003, Экспресс-выпуск 229: 768-787

Tyler S. J., 2004 - Family Motacillidae (Pipits and Wagtails). In: Handbook of the Birds of the World. Vol. 9. Cotingas to Pipits and Wagtails. del Hoyo, Elliott A. \& Christie D. (eds.). Lynx Edicions, Barcelona: 686-786.

University of Michigan Museum of Zoology, 2019 - University of Michigan Museum of Zoology, Division of Birds. Version 14.15. Occurrence dataset. <https://doi.org/10.15468/1ns1qm> (accessed via GBIF.org on 2019-10-29).

Valkenburg M., 2016 - Trip report Russia \& Mongolia 16 June - 01 July 2016. Rubythroat Birding Tours. <https://www. cloudbirders.com/be/download? filename $=$ RUBYTHROAT RussiaMongolia_0607_2016.pdf>

Van Beirs M. \& Khayankhayrvaa T., 2016 - Mongolia 21 May - 4/8 June 2016. BirdQuest. <https://www.birdquest-tours.com/wp-content/uploads/2019/06/MONGOLIA-REP-16-ebook.pdf>

van der Woude J., 2015 - Birding trip report Kazakhstan 1-16 May 2015. <http://www.jvanderw.nl/tripreports/Kaz2015/report. html>

van Duivendijk N., 2010 - The Advanced Bird Guide, Western Palearctic. New Holland, London.

van Someren V. G. L., 1931 - Catalogue of the European and Asiatic migrants to Kenya and Uganda, with brief outline of the subject of migration of birds. The Journal of the East Africa and Uganda Natural History Society, Special Supplement N. 4.

Vasudeva Rao V., Sravan Kumar R., Surender G. \& Laxmi Narayana B., 2014 - Diversity, Abundance and Variation of Water Birds at Kolleru Wetland in Andhra Pradesh. Biological Forum - An International Journal, 6 (2): 62-76.

Vaurie C., 1959 - The birds of the Palearctic fauna. Order Passeriformes. H. F. \& G. Witherby, London.

Vaurie C., 1960 - Family Motacillidae (Palearctic). In: Check-list of birds of the world: a continuation of the work of James L. Peters. Vol. 9. Mayr E. \& Greenway J. C. (eds.). Harvard University Press, Cambridge: $129-167$

Voelker G., 2002 - Systematics and historical biogeography of wagtails: dispersal versus vicariance revisited. The Condor, 104: 725739.

volgabirds.ru, 2019 - Forum. $<$ http://volgabirds.ru/forum/>

Vorobyov V. M., 2018 - Находки редких птиц в КатонКарагайском национальном парке (Южный Алтай). Русский орнитологический журнал, 27, Экспресс-выпуск 1607: 21872206.
Waite H. W., 1939 - Occurrence of the White-headed Wagtail [Motacilla flava leucocephala (Przewalski)] in the Attock District of the Punjab. Journal of the Bombay Natural History Society, 40 (3-4): 561.

Waite H. W., 1962 - Notes on the range of certain birds as given in S. D. Ripley II (1961): a synopsis of the birds of India and Pakistan. Journal of the Bombay Natural History Society, 59 (1): 958-963.

Wassink A., 2009a - Birds of Kazakhstan: new and interesting data, part 2. Dutch Birding, 31 (2): 101-110.

Wassink A., 2009b - Ornithological Trip Report Kazakhstan May 2009. <http://wildnature-kz.narod.ru/May2009-kazakhstan_birding_trip_report_AWassink.pdf $>$

Wassink A. \& Oreel G. J., 2008 - Birds of Kazakhstan: new and interesting data. Dutch Birding, 30: 93-100.

Weiwenku.org, 2019 - 踣鴒科. < https://www.weiwenku.org/ $\mathrm{d} / 200115393>$

Whistler H., 1916 - Notes on the Birds of the Jhelum District of the Punjab. The Ibis, 4 (Tenth Series): 35-117.

Whistler H., 1940 - The White-headed Wagtail (Motacilla flava leucocephala (Przew.)). The Ibis, 82 (2): 335-337.

Williams D., Dunkerley D., de Deckker P., Kershaw P. \& Chappell M., 1998 - Quaternary Environments. Arnold, London.

Williamson K., 1955 - Migrational drift and the Yellow Wagtail complex. British Birds, 48 (9): 383-403.

Willsher J. \& Willsher J., 2017 - Crete Naturetrek Tour Report 11 -18 April 2017. <https://d11gbzngntg4t4.cloudfront.net/reports/ GRC02_report_170411_Crete.pdf>

XIEG (Xinjiang Institute of Ecology and Geography, Chinese Academy of Sciences), 2011 - China: Sustainable Management and Biodiversity Conservation in the Lake Aibi Basin Environmental Impact Assessment Report, Xinjiang, China. <http://documents.worldbank.org/curated/en/822101468019750004/pdf/E27130V10REVIS1Box358341B01PUBLIC1.pdf>

Yakovlev V. A., Yakovlev A. A., Isakov G. N., Matveev A. V., Nikiforova V. V. \& Gorikhovsky V. G., 2012 - On ornithological findings in Chuvash Republic in 2008-2012. Бутурлинскийсборник, материалы IV международныхбутурлинскихчтений, Ульяновск, 19-22 сентября 2012 года. Ulyanovsk: 315-318.

Yardbirds, 2020 - בוהצ ילאילחנ. >https://www.yardbirds.org.il/show bird/101>

Yashina T. V., 2011 - Biodiversity assessment indicators for specially protected natural territories Altai-Sayan Ecoregion. Guide for use. Krasnoyarsk.

Yousuf N., William K., Manzoor M. \& Balqees K., 2015 - Description and distribution of Wagtails "Family Motacillidae" with reference to Pakistan. Journal of Bioresource Management, 2 (3): 82-85.

Zarudny N. A., 1911 - Verzeichnis der Vögel Persiens. Journal für Ornithologie, 59: 185-241.

Zhengjie Z., 2009 - A Handbook of the Birds of China. Volume 2 Passerines. Jilin Science and Technology Press. 